Eskişehir Osmangazi Üniversitesi iißBF Dergisi

Aralık 2020, C. 15, S. 3, $875-902$

Başvuru : 02.01.2019

Kabul : 31.03 .2020

\title{
Illerin Yaşam Kalitesi: Türkiye İstatistik Kurumu Verileriyle Veri Zarflama Analizi'ne Dayalı Bir Endeks
}

Atalay Çağlar ${ }^{1}$

IIllerin Yaşam Kalitesi: Türkiye İstatistik Kurumu Verileriyle Veri Zarflama Analizi'ne Dayalı Bir Endeks

\section{Öz}

TÜiK, Illerde Yaşam Endeksi ile bireylerin ve hanehalklarının yaşamını objektif ve subjektif ölçütler kullanarak yaşam boyutları ayrımında yerel düzeyde ölçmeye, karşılaştırmaya, zaman içinde izlemeye yönelik bir endeks çalışması yapmıştır. TÜik Yaşam Endeksi'nde 11 boyutta toplam 41 gösterge kullanılmaktadır. Yaşam Endeksi, minimum-maksimum normalizasyonu ile elde edilen alt endekslerin aritmetik ortalaması ile bulunmaktadır. Bu çalışmada alt endekslerin bulunmasında Veri Zarflama Analizi'nin kullanılması önerilmektedir. Ayrıca, illerin Yaşam Kalitesi Endeksi, elde edilen alt endekslerin geometrik ortalaması olarak alınmıştır. Önce illerin 2015 yılı Yaşam Kalitesi Endeksi, TÜik 2015 Yaşam Endeksi verileriyle ağırlık sınırlandırması yapılmadan elde edilmiştir. Daha sonra, illerin 2015 yılı Yaşam Kalitesi Endeksi, ağırlık sınırlandırması yapılarak bulunmuştur. Coğrafi olarak Türkiye'nin batısındaki illerin yaşam kalitesinin, doğudaki illerin yaşam kalitesinden daha yüksek olduğu görülmüştür.

Anahtar Kelimeler: Yaşam Kalitesi, Yaşam Kalitesi Endeksi, Veri Zarflama Analizi, Bölgesel Gelişme
Quality of Life of The Provinces: An Index Based on Data Envelopment Analysis with Turkish Statistical Institute Data

Abstract

With the Index of Life in Provinces, TURKSTAT has made an index study to measure, compare, monitor the life of individuals and households at the local level in the distinction of life dimensions using objective and subjective criteria. A total of 41 indicators are used in 11 dimensions in the TURKSTAT Life Index. Life Index is found with arithmetic average of sub-indices obtained by minimummaximum normalization. In this study, it is recommended to use Data Envelopment Analysis to find sub-indices. In addition, the Quality of Life Index of the provinces was taken as the geometric mean of the obtained sub-indices. The Quality of Life Index of the provinces in 2015 was obtained without weight restriction with the data of TURKSTAT 2015 Life Index. Then, the Quality of Life Index of the provinces in 2015 was determined by weight restriction. Geographically, the quality of life of the western provinces of Turkey was found to be higher than quality of life of the eastern provinces.

Keywords: Quality of Life, Quality of Life Index, Data Envelopment Analysis, Regional Development

\section{Giriş}

Sanayi Devrimi sonrasında kentleşme hızlanmış ve böylece insanların yaşam biçimlerinde ve kentlerin yapısında çok büyük değişiklikler ortaya çıkmıştır. Kentlerin çok hızlı büyümesi kırdan kente göçün artması, çevre kirliliğinin yaşamı tehdit edecek boyuta ulaşması, stres başta olmak üzere ortaya çıkan mutsuzluk kaynaklarının çoğalması vb. yapısal problemleri beraberinde getirmiştir. Bunun yanında, artan gelir, yükselen refah düzeyi ve iyileşen eğitim düzeyi insanların daha iyi koşullarda yaşama bilincini de geliştirmiştir. Daha iyi koşullarda yaşamanın kriterleri bireyin bulunduğu çevresel koşullar ve bu koşullara ilişkin bireyin algılarının bir bileşkesi olacaktır. Algılar ise bireyin bulunduğu çevreye, eğitimine, inançlarına, sosyoekonomik durumuna göre farklılık taşıyacaktır. Bu nedenlerle, insanların daha iyi yaşam koşullarını incelemek farklı açılardan çok sayıda ölçüt ile mümkün olabilecek çok boyutlu bir problemdir. Dolayısıyla, yaşam kalitesi kavramı daha iyi yaşamı ifade eden çok boyutun tek boyuta indirgenerek özetlenmesi olarak düşünülebilir.

1 Doç. Dr., Pamukkale Üniversitesi, iiBF, Ekonometri Bölümü, acaglar@pau.edu.tr, Yazar ORCID bilgisi: https://orcid.org/0000-0003-4936-5783 
Özellikle gelişmekte olan ülkelerin temel sorunlarından olan, kaynakların dağılımındaki ve nüfus kitlelerine sunulan refah ve yaşam koşullarındaki eşitsizlik sonucunda sosyal ve ekonomik problemler artmaktadır (Evcil Türksever, 2001: 2). Yaşam memnuniyeti yüksek olan toplumlarda bireylerin iş yaşamları verimli hale gelerek üretkenlikleri artacak, artan mutlulukları ve düzenli yaşamları daha sağlıklı olmalarını sağlayarak sağlık harcamalarını azaltacak, suç oranlarını azaltarak güvenlik ve adalet sisteminin düzenli ve düşük maliyetli olmasını sağlayacaktır. Ayrıca yaşam memnuniyetsizliğinin bir sonucu olarak yaşanabilecek göçlerin önüne geçilerek uzun dönemli yapılan altyapı planlamalarının karşılı̆ıını bulması ve göçün yaratabileceği ek sorunların önüne geçilmesi mümkün olacaktır. O halde, bireylerin yaşam kalitesinin bir sonucu olarak nitelenebilecek yaşamlarından memnuniyeti sosyoekonomik sorunların önüne geçilerek toplumun düzenli olmasına yardımcı olacaktır.

Yaşam kalitesi kavramı mimarlık, şehir ve bölge planlama gibi bilimlerin yanında tıbbi bilimlerden sosyal bilimlere kadar pek çok disiplinin ilgisini çekmektedir. Bu derece farklı alandaki çalışmaların odaklanması nedeniyle, her alan kendine has irdelemeler yaptığından yaşam kalitesi için pek çok farklı tanım yapılabilir. Hangi disiplinde ve nasıl tanımlanırsa tanımlansın insan yaşamının kalitesi, yaşadığı bölgedeki altyapıdan, aldığı eğitime, sahip olduğu ekonomik seviyeden oturduğu evin kalitesine kadar birçok faktörden etkilenmektedir. Bu durum, günümüzde iyi yaşamın tanımlanmasında ve ölçülmesinde birçok değişken ve göstergeden yararlanılmasını zorunlu hale getirmektedir (Alpaykut, 2017: 368). Ancak, tüm bu ölçütlerde asıl sorun, yaşam kalitesini değerlendirmek için seçilen faktörlerde seçim yanlılığı ve keyfiliktir. Daha da önemlisi, farklı göstergelerden tek bir bileşik ölçü elde etmek için göstergelere ilişkin ağırIıkların belirlenmesidir (The Economist Intelligence Unit, 2005: 1). Bu anlamda literatürdeki çalışmaların bir bölümü yaşam kalitesinin belirlenmesinde kullanılabilecek göstergelerin seçimini irdelemektedir. Diğer bir bölümü de seçilen göstergelerin ağırlıklarının belirlenmesini ve elde edilecek endeksin bulunmasındaki yönteme ilişkindir. Bu çalışmada illerin yaşam kalitesi belirlenirken kullanılabilecek göstergeler hakkında bir tartışma yapılmadan Türkiye İstatistik Kurumu (TÜIK) tarafından belirlenen göstergelere yer verilmiştir. Çalışmada illerin yaşam kalitesi endeksinin oluşturulmasında Mahlberg ve Obersteiner (2001) tarafından önerilen Veri Zarflama Analizi'ne dayalı bir model kullanıımıştır. Modelde göstergelere ilişkin ağırlıkların belirlenmesi için önsel bir bilgiye ihtiyaç duyulmamaktadır ve model her birimin kendi performansını en iyi yapacak ağırlık kümesini kullanmaktadır. Çalışmada Tüik tarafından kullanılan 11 alt boyutun her biri için bir alt endeks elde edilmiştir. Daha sonra her boyutun endeks değerlerinin geometrik ortalaması alınarak bir genel yaşam kalitesi endeksi oluşturulmuştur. Aynı işlemler ağırlık sınırlandırması altında tekrar uygulanmış ve böylece modelin ayırma gücünün artırılarak illerin yaşam kalitesi boyutlarındaki alt endekslere ve genel endekse göre sıralanması sağlanmıştır.

Çalışmanın sonraki bölümünde yaşam kalitesinin kavramsal çerçevesinden bahsedilirken, daha sonra yaşam kalitesi konusunda Dünya'da ve Türkiye'de yapılan çalışmalara değinilmiştir. Çalışmanın amacı, çalışmada kullanılan yöntem ve veri hakkında bilgiler verildikten sonra çalışmanın bulguları paylaşılmıştır. Son bölümde elde edilen sonuçlar tartışılmıştır.

\section{Yaşam Kalitesi}

Yaşam kalitesi kavramı, çağdaş toplumların ortaya çıkması ve yaşamın modernleşmesi ile birlikte gündeme gelen bir konudur (Pacione, 2003: 19). Ancak, kavramın tarihsel kökenlerini Antik Yunan filozoflarına kadar götürmek mümkündür. Kökeni bu kadar eskilere dayanan bu kavram, bulunduğu çağın koşullarına ve ele alındığı bakış açısına göre farklı şekillerde yorum- 
lanagelmiştir (Sarı ve Kındap, 2018: 44). Yaşam kalitesi ile ilgili literatür incelendiğinde farklı disiplinlerin yaşam kalitesine yönelik farklı yaklaşımlar geliştirdiği, hatta aynı disiplin içinde değişik yaklaşımlar olduğu gözlenmektedir (Farquhar, 1995: 502). Hoe vd. (2011)'e göre evrende var olan insan sayısı kadar yaşam kalitesi tanımı yapılması mümkündür.

Yaşam kalitesi kavramı sosyal bilimcilere toplumların yaşam koşullarındaki farklılıkların ve eşitsizliklerin ortaya konulması fırsatını vermektedir. Toplumun tüm katmanlarının yaşam koşullarındaki iyilik refah seviyesinin yüksek olduğunu akla getirmektedir. 20. yüzyılın son çeyreğine kadar bireylerin, bölgelerin, ülkelerin refahı gelir ile ifade edilmektedir. Teknolojinin gelişmesi ve gelir düzeyinin yükselmesiyle birlikte, maddi zenginliğin tek başına yaşam kalitesinin bir göstergesi olmadığı; mekânsal, toplumsal ve hatta siyasal etmenlerin de bireyin yaşam kalitesinde etkili olduğu ortaya çıkmıştır (Koçak, 2009: 143).

Dünya Sağlık Örgütü, yaşam kalitesini bireylerin yaşamdaki konumlarının, içinde yaşadıkları kültür ve değer sistemleri bağlamında, hedefleri, beklentileri, standartları ve endişeleri ile bağlantılı olarak algılaması olarak tanımlamaktadır. Yaşam kalitesi, kişinin fiziksel sağlığı, psikolojik durumu, bağımsızlık düzeyi, sosyal ilişkileri, kişisel inançları ve çevresiyle olan ilişkileriyle karmaşık bir şekilde etkilenen geniş kapsamlı bir kavramdır (WHOQOL, 1997: 1).

Yaşam kalitesi, bir bireyin yaşam tarzı, sağlığı ve toplumla ilişkisinin nicel ve nitel değerlerinin toplamı olarak düşünülebilir (Şeker, 2015: 1). İnsanın fiziksel, mekânsal, çevresel, toplumsal ve ekonomik gereksinimlerinin karşılanma düzeyi ile bireylerin bu düzeylerden duyduğu memnuniyetlerin toplamı yaşam kalitesini ortaya çıkarmaktadır (Ören Ersin, 2012: 22). Yaşam kalitesi, insanın sağlıklı bir ortamda yaşayabilmesi, beslenme, korunma, barınma gereksinimlerini karşılayabilmesi, bedensel, ruhsal gelişmesine uygun olanakları bulabilmesi, yaratıcı gücünü kullanabilmesi, doğal ve yapay yaşam ortamlarının birbiriyle dengeli uyumunu yansıtması$\operatorname{dır}$ (Geray, 1998: 327).

Yaşam kalitesinin değerlendirilmesinde kullanılacak değişken ya da göstergelerin belirlenmesi önemli bir konudur. Daha önce belirtildiği gibi belli bir dönemde gayrı safi yurtiçi hasıla, kişi başına gelir gibi gelire dayalı göstergeler kullanılsa da bu göstergelerin yaşam kalitesini tam olarak yansıtamayacağı, eksiklik taşıyacağı açıktır. Dolayısıyla, tanımına uygun olarak pek çok farklı açıdan değerlendirme olanağı tanıyacak gösterge seçiminin yapılması gerekmektedir. Yaşam kalitesi kavramı ve araştırma alanı ilk olarak, Sosyal Göstergeler Hareketi çerçevesinde oluşmuştur (Kısar Koramaz, 2010: 6). Sosyal göstergeler hareketinin göstergelere ilişkin gruplamasında, objektif (nesnel) göstergeleri kullanan İskandinav ve öznel (subjektif) göstergeleri kullanan Amerikan yaklaşımı olmak üzere iki yaklaşımdan bahsetmek mümkündür (Salihoğlu, 2016: 19). İskandinav yaklaşımında bir insanın yaşam koşullarını kontrol edip bilinçli bir şekilde yönlendirebileceği kaynaklar kullanılmaktadır. Kaynaklar para, mal, bilgi, psişik ve fiziksel enerji, sosyal ilişkiler, güvenlik vb. ile tanımlanmaktadır. Bu yaklaşımda, nesnel yaşam koşulları ve belirleyicilerine odaklanılmaktadır. İskandinav yaklaşımının tersine, Amerikan yaklaşımı memnuniyet ve mutluluk gibi öznel göstergelere dayanmaktadır (Noll, 1996: 5).

Yaşam kalitesinin değerlendirilmesinde nesnel ve öznel göstergelerden yalnızca bir tanesini kullanacak araştırmaların kavramı açıklamada ve değerlendirmede yetersiz olacağı belirtilmektedir. Sosyal (objektif) göstergeler ve öznel iyi oluş göstergeleri tamamlayıcı niteliktedir. Bireylerin bakış açılarını yansıtacak subjektif ölçütler, insanların kaygılarını, kamu fonlarına olan taleplerini ve ihtiyaçları için acil taleplerini dile getirebilecekleri bir yol sağlar. Bununla birlikte, nesnel standartlara dayanan ölçütlere toplumun koşullarını belirlemek için de ihtiyaç 
duyulmaktadır, çünkü insanlar istenmeyen birçok durumda bile bir şekilde mutlu olabilirler (Diener ve Suh, 1997: 207).

Yaşam kalitesi göstergeleri kullanılarak yapılan çalışmalar yerel ve ulusal yönetimlere; birey, grup ya da toplumların demografik, sosyal ve ekonomik profilini belirleme, mevcut yaşam kalitesi düzeyini geliştirmek için hedefler saptama ve yaşam kalitesi konusunda mevcut konumlarını ulusal veya uluslararası düzeyde başka birimlerle kıyaslama imkânını vermektedir (Kaya vd., 2011: 85). Ülkelerde ya da bölgelerde yaşam kalitesinin belirlenmesine yönelik çok sayıda endeks çalışması ve bu çalışmaları içeren çok sayıda yayın bulunmaktadır. Farklı göstergelerin ve farklı yöntemlerin kullanıldığı bu çalışmalardan ilk akla gelen Birleşmiş Milletler Kalkınma Programı (UNDP) tarafından ülkeler için 1990 yılından itibaren hesaplanan İnsani Gelişme Endeksi'dir. Üç alt boyuttan elde edilen endekslerin geometrik ortalaması alınarak bulunan İnsani Gelişme Endeksi hesaplamalarına son olarak en güncel 2017 verileri ile 189 ülke dahil edilmiştir (UNDP, 2018a: 2; 2018b: 2). The Economist Intelligence Unit tarafından 2005 yılında 111 ülke için 9 bileşendeki göstergelerle Yaşam Kalitesi Endeksi hesaplanmıştır (The Economist Intelligence Unit, 2005: 1-2). Ayrıca, aynı birim tarafından sonuncusu 2017 yılında olmak üzere 140 dünya kenti için 5 kategorideki 30 gösterge ile Global Yaşanabilirlik Endeksi açıklanmaktadır (The Economist Inteligence Unit, 2017: 2, 8, 9). European Foundation for the Improvement of Living and Working Conditions (EUROFOND) birincisini 2003 yılında olmak üzere her dört yılda bir Avrupa Yaşam Kalitesi Anketi uygulamaktadır. 2016 yılında uygulanan son ankette 28 üye ülke ve aralarında Türkiye'nin de bulunduğu 5 aday ülke ile beraber toplam 33 ülkeye ilişkin bulgular yayımlanmıştır (Eurofound, 2017: 6, 9). 2018 yılında 200 'den fazla dünya kentinin incelendiği ve 10 kategoride elde edilen 39 göstergeden hesaplanan Mercer'in Yaşam Kalitesi endeksi en bilinen endekslerden bir diğeridir (Beritan, 2014: 100-101). İngiltere'de yayınlanan Monocle dergisi 2006 yılından itibaren, her yıl yaşanabilir şehirlerin bir listesini yayımlamaktadır. 2008 yılında En Yaşanabilir Şehirler Endeksi adı verilen endeks ile dünyanın en yaşanabilir 25 kenti belirlenmektedir (Sarkawi vd., 2017: 586-587). Çerçevesi 2011 yılında oluşturulan Ekonomik İşbirliği ve Kalkınma Örgütü (OECD) Daha İyi Yaşam Endeksi ise ülkeler arasındaki refahı karşılaştırmaktadır. Daha İyi Yaşam Endeksi ile 2017 yılında 11 boyutta 24 gösterge kullanılarak 41 ülke (Kolombiya, Kosta Rika, Litvanya, Brezilya, Rusya Federasyonu, Güney Afrika ve 35 OECD üyesi) incelenmiştir (OECD, 2017: 17, 23-25). Bu çalışmalarının dışında farklı gösterge ya da yöntemlerle uygulanan pek çok akademik çalışma da bulunmaktadır. Bu çalışmaların bir kısmı Veri Zarflama Analizi modellerinden faydalanmaktadır. Veri Zarflama Analizi veya benzeri modellerle yapılan yaşam kalitesi çalışmaları için Bernini vd. (2013), Gonzalez vd. (2011), Gonzalez vd. (2011), Hashimoto vd. (2009), Hwang vd. (2013), Mariano vd. (2015), Martín ve Mendoza (2013), Peiró-Palomino ve PicazoTadeo (2018), Põldaru ve Roots (2014), Somarriba ve Pena (2009), Zhu (2001) incelenebilir.

\section{Türkiye'deki illerin Yaşam Kalitesinin Belirlenmesine illişkin Literatür}

Türkiye'de illerin veya bölgelerin yaşam kalitesine ilişkin farklı yöntemlerle ve farklı göstergelerle çalışmalar yapılmıştır. Bu çalışmaların bir kısmı sosyoekonomik gelişmişliğe odaklanmıştır. Yaşam kalitesinin sosyoekonomik gelişmişlik ile iç içe geçtiği düşünüldüğünde bu çalışmalara değinmek faydalı olabilir. Bu çalışmalarda genel olarak Temel Bileşenler Analizi, Güçlü Temel Bileşenler Analizi, Faktör Analizi, Kümeleme Analizi, vb. çok değişkenli istatistiksel yöntemler kullanılmıştır. Devlet Planlama Teşkilatı, 1996 ve 2003 yıllarında illerin ve 2004 yılında ilçelerin sosyoekonomik gelişmişliğini araştırmıştır (Tunca, 2017: 347). Kalkınma Bakanlığı 2013 yılında illerin Sosyo-Ekonomik Gelişmişlik Endeksi (SEGE-2011)'ni oluşturmuştur. Ayrıca, 
Albayrak (2015), Atan vd. (2004), Baday Yıldız vd. (2012), Filiz (2005), Gül ve Çevik (2014, 2015), Karaatli vd. (2015), Sakarya ve İbişoğlu (2015), Şen vd. (2006), Ünsal ve Özgür (2004), Yılancı (2010) çalışmalarında illerin sosyoekonomik gelişmişliği incelenmiştir. Gülel vd. (2017), Özpınar ve Koyuncu (2016), Yeşilyurt vd. (2016) ve Çağlar ve Keten (2018) çalışmalarında ise illerin insani gelişmişlik endeksi hesaplanarak yorumlanmıştır.

Türkiye'deki iller veya bölgeler için doğrudan yaşam kalitesini belirleme amacını taşıyan çaış̧malar da mevcuttur. Bu çalışmaların bir kısmı ilgili bölgede anket uygulanarak veya bölgeye ilişkin sosyoekonomik göstergeler kullanılarak yürütülmüştür. Evcil Türksever (2001) İstanbul, Ankara, İzmir, Gaziantep, Adana ve Antalya büyükşehir belediye sınırları içinde yaşayanların yaşamdan memnuniyetine etki eden faktörleri araştırmıştır. Ülengin vd. (2001) İstanbul'da yaşayanların yaşam kalitelerini artırabilmek için İstanbulluların ihtiyaçlarını, önceliklerini ve beklentilerini belirlemişlerdir. Savaş Yavuzçehre ve Torlak (2006) Denizli örneği ile belediyelerin kentsel yaşam kalitesine etkilerini ele almıştır. Dülger Türkoğlu vd. (2008) İstanbul'da 1635 hanehalkına uygulanan anket ile isstanbul'da yaşam kalitesinin portresinin oluşturulmasına çalışmıştır. Torlak ve Savaş Yavuzçehre (2008) Denizli'de kent yoksullarının subjektif yaşam kalitesi algılarını incelemiştir. Gürel Üçer (2009) bir yaşam kalitesi rehberi hazırlamış ve 22 adet orta ölçekli il merkezi belediyesinde alan çalışması yaparak kentleri yaşam kalitesine göre sıralamıştır. Çam (2014) Kastamonu için şehir yaşam kalitesini ölçerek şehirlerin pazarlanmasında ön plana çıkabilecek şehir yaşam faktörlerini tespit etmeye çalışmıştır. Şeker (2015) İstanbul'daki 39 ilçe için bir yaşam kalitesi endeksi hazırlamıştır. Şeker vd. $(2014,2015)$ TRC2 ve TR63 bölgeleri için yaşam kalitesini incelemiştir. Karagöz vd. (2016) gelir düzeyi ile yaşam kalitesi ve memnuniyeti arasındaki doğru yönlü ilişkinin varlığını Sivas ili örneğinde ortaya koymaya çalışmıştır. Bodur ve Dulgeroğlu Yuksel (2017) İstanbul'da gecekondularda yaşayan ve sosyal konuta taşınanların yaşam kalitesinde ortaya çıkan değişimi inceleyerek yerel yönetimlere önerilerde bulunmuştur.

Son yıllarda TÜik illerde Yaşam Endeksi sonuçlarının irdelendiği ya da aynı göstergelerin kullanılmasıyla endeksin yeniden hesaplandığı çalışmalar göze çarpmaktadır. Tüik, illerde Yaşam Endeksi ile bireylerin ve hanehalklarının yaşamını objektif ve subjektif ölçütler kullanarak yaşam boyutları ayrımında yerel düzeyde ölçmeye, karşılaştırmaya ve zaman içinde izlemeye yönelik bir endeks çalışması yapmıştır. İllerde Yaşam Endeksi çalışmasının temel amacı ildeki yaşamın tüm boyutları ile izlenmesine ve iyileştirilmesine altlık oluşturacak bir gösterge sistemi geliştirmektir. İllerde Yaşam Endeksi, yaşamın maddi yönlerini içerdiği kadar, geneli hakkındaki öznel algı, sosyal yaşam, yaşam memnuniyeti ve yaşanılan çevre gibi kavramları da içine katacak şekilde yaşamın bütün yönlerini kapsayan bir çalışmadır. İllerde Yaşam Endeksi çalışmasının boyut ve göstergeleri belirlenirken OECD’nin Daha İyi Yaşam Endeksi çerçevesi ve Türkiye koşulları temel alınmıştır. Yaşam Endeksi, birey yaşamı üzerinde büyük etkisi olan 11 boyut altında toplam 41 göstergeyi içerecek şekilde hazırlanmıştır. 81 il için Tablo 1'de verilen TÜiK Yaşam Endeksi'nde kullanılan boyutlar ve göstergeler yardımıyla önce yaşam boyutlarına ilişkin ayrı ayrı alt endeks değerleri hesaplanmış, daha sonra bu alt endekslerin aritmetik ortalaması alınarak genel endeks değeri elde edilmiştir (TÜiK, 2018: 1-2). Alt endeksler belirlenirken, ilgili boyuttaki göstergeler minimum-maksimum normalizasyonu ile normalize edildikten sonra her biri ait olduğu boyut içinde eşit ağılıkta alınarak hesaplama yapılmıştır. Yine, Yaşam Endeksi belirlenirken alt endeksler de eşit ağırlıkta kullanılmıştır. 2015 yılı Yaşam Endeksi sonuçlarına göre ilk üç sırayı Isparta, Sakarya ve Bolu alırken son üç sırada Ağrı, Mardin ve Muş bulunmaktadır. Genel endekse göre İstanbul 5., Ankara 17. ve İzmir 21. sıradadır. 
Eskişehir Osmangazi Üniversitesi ïBF Dergisi

Tablo 1: TüiK Yaşam Endeksi'nde Kullanılan Boyutlar ve Göstergeler

\begin{tabular}{|c|c|c|c|c|c|}
\hline Boyutlar & Göstergeler & $\begin{array}{l}\text { Katkı } \\
\text { Yönü }\end{array}$ & Boyutlar & Göstergeler & $\begin{array}{l}\text { Katkı } \\
\text { Yönü }\end{array}$ \\
\hline \multirow{3}{*}{ Konut } & Fert başına düşen oda sayısı & Pozitif & \multirow{5}{*}{ Çevre } & $\begin{array}{l}\text { PM10 istasyon değerleri } \\
\text { ortalaması }\end{array}$ & Negatif \\
\hline & $\begin{array}{c}\text { Konutun içinde tuvalet } \\
\text { mevcudiyeti oranı }\end{array}$ & Pozitif & & $\mathrm{Km}^{21}$ ye düşen orman alanı & Pozitif \\
\hline & $\begin{array}{c}\text { Konutun kalitesinde problem } \\
\text { yaşayanların oranı }\end{array}$ & Negatif & & $\begin{array}{c}\text { Atık hizmeti verilen nüfusun } \\
\text { oranı }\end{array}$ & Pozitif \\
\hline \multirow{4}{*}{$\begin{array}{l}\text { Çalışma } \\
\text { Hayatı }\end{array}$} & İstihdam oranı & Pozitif & & $\begin{array}{c}\text { Sokaktan gelen gürültü } \\
\text { problemi yaşayanların oranı }\end{array}$ & Negatif \\
\hline & İşsizlik oranı & Negatif & & $\begin{array}{l}\text { Belediyenin temizlik hizmet- } \\
\text { lerinden memnuniyet oranı }\end{array}$ & Pozitif \\
\hline & Ortalama günlük kazanç & Pozitif & \multirow{4}{*}{ Güvenlik } & $\begin{array}{c}\text { Cinayet oranı (bir milyon } \\
\text { kişide) }\end{array}$ & Negatif \\
\hline & İşinden memnuniyet oranı & Pozitif & & $\begin{array}{l}\text { Ölümlü ve yaralanmalı trafik } \\
\text { kazası sayısı (bin kişide) }\end{array}$ & Negatif \\
\hline \multirow{3}{*}{$\begin{array}{l}\text { Gelir } \\
\text { ve } \\
\text { Servet }\end{array}$} & $\begin{array}{c}\text { Kişi başına düşen tasarruf } \\
\text { mevduatı }\end{array}$ & Pozitif & & $\begin{array}{l}\text { Gece yalnız yürürken kendini } \\
\text { güvende hissedenlerin oranı }\end{array}$ & Pozitif \\
\hline & $\begin{array}{c}\text { Orta ve üstü gelir grubundaki } \\
\text { hanelerin oranı }\end{array}$ & Pozitif & & $\begin{array}{l}\text { Kamunun asayiş hizmetlerin- } \\
\text { den memnuniyet oranı }\end{array}$ & Pozitif \\
\hline & $\begin{array}{c}\text { Temel ihtiyaçlarını karşıla- } \\
\text { yamadığını beyan eden } \\
\text { hanelerin oranı }\end{array}$ & Negatif & \multirow{3}{*}{$\begin{array}{c}\text { Sivil } \\
\text { Katılım }\end{array}$} & $\begin{array}{l}\text { Mahalli idareler seçimlerine } \\
\text { katılım oranı }\end{array}$ & Pozitif \\
\hline \multirow{5}{*}{ Sağlık } & Bebek ölüm hızı & Negatif & & Siyasi partilere üyelik oranı & Pozitif \\
\hline & $\begin{array}{c}\text { Doğuşta beklenen yaşam } \\
\text { süresi }\end{array}$ & Pozitif & & $\begin{array}{l}\text { Sendika/dernek faaliyetleri } \\
\text { ile ilgili olanların oranı }\end{array}$ & Pozitif \\
\hline & $\begin{array}{l}\text { Hekim başına düşen müra- } \\
\text { caat sayısı }\end{array}$ & Negatif & \multirow{4}{*}{$\begin{array}{l}\text { Altyapı } \\
\text { Hizmetlerine } \\
\text { Erişim }\end{array}$} & $\begin{array}{l}\text { İnternet abone sayısı (yüz } \\
\text { kişide) }\end{array}$ & Pozitif \\
\hline & $\begin{array}{c}\text { Sağlığından memnuniyet } \\
\text { oranı }\end{array}$ & Pozitif & & $\begin{array}{l}\text { Kanalizasyon ve şebeke } \\
\text { suyuna erişim oranı }\end{array}$ & Pozitif \\
\hline & $\begin{array}{c}\text { Kamunun sağlık hizmetlerin- } \\
\text { den memnuniyet oranı }\end{array}$ & Pozitif & & Havalimanına erişim oranı & Pozitif \\
\hline \multirow{6}{*}{ Eğitim } & $\begin{array}{l}\text { Okul öncesi eğitimde (3-5 } \\
\text { yaş) net okullaşma oranı }\end{array}$ & Pozitif & & $\begin{array}{c}\text { Belediyenin toplu taşıma } \\
\text { hizmetlerinden memnuniyet } \\
\text { oranı }\end{array}$ & Pozitif \\
\hline & $\begin{array}{l}\text { TEOG sistemi yerleştirmeye } \\
\text { esas puan ortalaması }\end{array}$ & Pozitif & \multirow{4}{*}{$\begin{array}{l}\text { Sosyal } \\
\text { Yaşam }\end{array}$} & $\begin{array}{l}\text { Sinema ve tiyatro seyirci } \\
\text { sayısı (yüz kişide) }\end{array}$ & Pozitif \\
\hline & YGS puan ortalaması & Pozitif & & $\begin{array}{c}\text { Bin kişi başına düşen alışveriş } \\
\text { merkezi alanı }\end{array}$ & Pozitif \\
\hline & $\begin{array}{c}\text { Fakülte veya yüksekokul } \\
\text { mezunlarının oranı }\end{array}$ & Pozitif & & $\begin{array}{c}\text { Sosyal ilişkilerinden memnu- } \\
\text { niyet oranı }\end{array}$ & Pozitif \\
\hline & $\begin{array}{l}\text { Kamunun eğitim hizmetle- } \\
\text { rinden memnuniyet oranı }\end{array}$ & Pozitif & & $\begin{array}{c}\text { Sosyal hayatından memnuni- } \\
\text { yet oranı }\end{array}$ & Pozitif \\
\hline & & & $\begin{array}{c}\text { Yaşam } \\
\text { Memnuniyeti }\end{array}$ & Mutluluk düzeyi & Pozitif \\
\hline
\end{tabular}

Kaynak: (TÜiK, 2018: 13)

Beşel (2015) TÜik 2013 yılı Yaşam Memnuniyeti Araştırması sonuçlarına göre düşük ve yüksek endeks değerine sahip illerin ekonomik, sosyal ve politik göstergelerini dikkate alarak mutluluk düzeylerinde bir etkisi olup olmadığını araştırmıştır. Çalışmada, mutlu illerdeki işsizlik oranı, ildeki konut satışının Türkiye satışlarına oranı, genel bütçe vergi gelirlerinin toplam tahsilat içindeki payı, genel bütçe vergi gelirleri tahsilat/tahakkuk oranı mutsuz illere göre düşük bulunmuştur. Ayrıca, mutlu illerde boşanma hızı, kişi başına elektrik tüketimi, nüfus 
yoğunluğu mutsuz illere göre düşük iken ilkokullarda net okullaşma oranı ve yüz bin kişi başına düşen hastane yatak sayısı daha fazladır. Dikmen ve Dursun (2016) TÜik 2015 verileriyle Türkiye'deki illerin yaşam kalitesini MULTIMOORA yöntemini kullanarak incelemiştir. Çalışmada, Oran, Referans Noktası, Tam Çarpımsal ve Sıra Baskınlık Yaklaşımı olmak üzere dört yaklaşımı temel alan MULTIMOORA kullanılmış ve tüm yaklaşımlardan elde edilen sonuçlar TÜík'in sıralamasından oldukça farklı bulunmuştur. Aydın ve Ertürk (2017) İstatistikî Bölge Birimleri Sınıflaması Düzey 2'ye göre bölgesel haritalar oluşturarak illerdeki Yaşam Memnuniyeti Endeksi ve başka göstergeler arasındaki ilişkiyi incelemiştir. Oluşturulan haritalarla endekslere göre bölgesel farklılıklar görülmüştür. Yaşam memnuniyeti endeks sonuçları geri kalmış bölgeler için geri kalmışlıkla anlamlı sonuçlar verirken, ülkenin gelişmişlik düzeyinin oldukça yüksek olduğu Marmara ve Akdeniz bölgeleri yaşamdan memnuniyetsizliğin yüksek olduğu bölgeler olarak ifade edilmiştir. Alpaykut (2017) yaşam memnuniyetini etkileyen faktörlerin farklı ağırlıklara sahip olması gerektiği düşüncesinden hareketle TÜik verileriyle illerdeki Yaşam Endeksi'ni TOPSIS yöntemi ile yeniden hesaplamıştır. Çalışmada boyutlara ilişkin ağırlıkların belirlenmesinde Temel Bileşenler Analizi'nden faydalanılmıştır. Elde edilen sonuçlarda i̇stanbul, Ankara ve İzmir Türkiye'de en iyi yaşamın olduğu üç il; Mardin, Şanlıurfa ve Siirt düşük yaşam koşullarının olduğu üç il olarak belirlenmiştir. Ayyıldız ve Demirci (2018) Türkiye'deki 81 şehrin yaşam kalitesini belirlemek için TÜik Yaşam Endeksi'ndeki 41 farklı göstergeyi ele almıştır. Bu göstergeleri kullanarak TOPSIS yöntemi ile 11 endeks oluşturularak gruplanmış ve SWARA yöntemiyle endeks ağırlıkları elde edilmiştir. Son olarak bulunan ağırlıklar kullanılarak TOPSIS yöntemiyle şehirler yaşam kalitesine göre sıralanmıştır. Sonuçlar incelendiğinde ekonomik olarak gelişmiş şehirlerde yaşam kalitesinin daha yüksek olduğu tespit edilmiştir. Özarı ve Eren (2018) TÜik Yaşam Endeksi'ndeki 11 endekse ilişkin 41 göstergeye göre Çok Boyutlu Ölçekleme ile illerin yapısını incelemiştir. Daha sonra k-ortalamalar algoritmasıyla illeri altı kümeye ayırmıştır. Her iki yöntemde de i̇stanbul'un tek başına değerlendirilmesi gerektiği görülen çalışma sonunda benzer iller belirlenmiştir. Uysal vd. (2017) Türkiye'de yaşam endeksi değerlerine göre farklılık veya benzerlik gösteren illeri ortaya koymak amacıyla Tüik Yaşam Endeksi'ndeki 11 endeks değerlerini kullanarak k-ortalamalar kümeleme analizi ile illeri kümelemiş ve daha sonra elde edilen sonuçları diskriminant analizi ile desteklemiştir. Çalışma sonucunda söz konusu değişkenlere göre iller üç kümeye ayrılmıştır. Ayırma fonksiyonu katsayılarına göre, illeri kümelere ayırmada "Konut" ve "Çalışma Hayatı" önemli ayırt edici bağımsız değişkenler olarak bulunmuştur. Bulut (2019)'da Uysal vd. (2017) ile benzer biçimde Tüik Yaşam Endeksi'ndeki 11 endekse göre illeri kümelemiştir. Çalışma sonunda iller, EM algoritmasına göre iki ve k-ortalamalar algoritmasına göre beş kümeye ayrılmıştır. Ayrıca, çalışmada kullanılan endeksler açısından elde edilen kümeler arasındaki farklııklar da incelenmiştir. Acar (2019) 2015 yılı için TÜik'den alınan illerde Yaşam Endeksi değerleri kullanılarak yaşam memnuniyetini etkileyen faktörleri belirlemeye çalışmıştır. İ bazında yaşam memnuniyetinin bağımlı değişken olduğu çalışmada kullanılan beş farklı ekonometrik modelde TÜik illerde Yaşam Endeksi'ndeki 8 alt endeksin değeri (Konut, Çalışma Hayatı, Gelir-Servet, Sağlık, Eğitim, Çevre, Güvenlik ve Sosyal Yaşam) ortak bağımsız değişken olarak yer almıştır. Çalışmada yaşam memnuniyetini etkileyen değişkenlerden en önemlisinin konut olduğu bulunmuştur. Daha sonra, güvenlik ve sosyal yaşam gelirken, gelir ve servet değişkeninin yaşam memnuniyetini etkilemediği görülmüştür. Özbek (2019) Türkiye'deki illeri, TÜik'in 2015 yılında yayımlamış olduğu illerde Yaşam Endeksi'ndeki 11 endeksin değerini kullanarak EDAS ve WASPAS yöntemlerine göre sıralamıştır. TÜiK sonuçları ile karşılaştırılan çalışma sonunda, üst sıralarda yer alan illerin Türkiye'nin Batı, alt sıralarda yer alan illerin ise Güneydoğu ve Doğu bölgelerinde yer aldığı 
belirtilmiştir. Yine, Yüce (2018) yaşam memnuniyeti endeksi dışındaki 10 endeks verisini kullanarak bir diğer çok kriterli karar verme yöntemi olan VIKOR ile illerin sıralamasını elde etmiştir. Kriterlerin ağılıklarının piyasa uzmanı kişilerle yapılan görüşmelerle belirlendiği çalışmada ilk sırada Isparta, ikinci sırada Karabük ve üçüncü sırada ise Trabzon yer almaktadır. Muş, Şırnak ve Ağrı ise son sıralalarda bulunmuştur.

\section{1. Çalışmanın Amacı}

Yaşamı bir bütün olarak ele alan, ekonomik boyutun yanı sıra yaşamın diğer boyutlarını da içine alan bir kavram olan toplumsal ilerlemenin ölçümüne yönelik çalışmalar yoğunluk kazanmıştır. Birey odaklı bu yeni ölçümde objektif ölçütler ve bireylerin öznel algıları birlikte kullanılmaktadır (TÜiK, 2018: 1). TÜiK Yaşam Endeksi bu amaçlara hizmet ederken aynı zamanda illerin eşitsizliklerini ya da eksikliklerini ortaya koyan bir endeks olarak görülmektedir. Yaşam Kalitesi Endeksi'nin hesaplanmasında önemli noktalardan bir tanesi her alt endeksteki göstergelere ilişkin ağırlıkların belirlenmesidir. Bir diğer zorluk da, genel bir endeksin oluşturulmasında alt endekslerin ağırlıklarının belirlenmesidir. TüiK Yaşam Endeksi'ndeki alt endeksler belirlenirken, ilgili boyuttaki göstergeler minimum-maksimum normalizasyonu ile normalize edildikten sonra her biri ait olduğu boyut içinde eşit ağılıkta alınarak hesaplama yapılmıştır. Yine, alt endeksler de aynı önemde düşünülerek aritmetik ortalaması alınmış ve Yaşam Endeksi hesaplanmıştır. Bu çalışmada, TÜik Yaşam Endeksi'nin her boyutuna ilişkin alt endekslerin belirlenmesi için Mahlberg ve Obersteiner (2001) tarafından İnsani Gelişme Endeksi'nin yeniden hesaplanmasında kullanılan model önerilmektedir. Mahlberg ve Obersteiner (2001)'in Veri Zarflama Analizi benzeri modeli ile alt endeksler belirlendikten sonra Yaşam Kalitesi Endeksi (YKE)'nin bulunmasında alt endekslerin geometrik ortalamasının alınması önerilmektedir. Bu çerçevede, çalışmada illerin yaşam kalitesinin belirlenmesinde Tüik tarafından önerilen göstergeler ile Veri Zarflama Analizi'ne dayalı bir endeks hesaplanması amaçlanmıştır. Böylece, hem illeri göreceli olarak değerlendiren ve hem de hesaplamada kullanılan göstergelerin ağılıklarının belirlenmesi problemini ortadan kaldıran bir yaklaşımın ortaya konulması hedeflenmiştir. Önerilen yöntemde gösterge ağılıklarının belirlenmesine ihtiyaç duyulmamakta, göstergelerin normalize edilmeden kullanılması mümkün olmaktadır.

\subsection{Yöntem}

Benzer girdileri kullanarak benzer çıktılar üreten işletme, kurum, okul, banka, mahkeme gibi birimlere 'Karar Verme Birimi (KVB)' denir. KVB'nin, elindeki en uygun girdi bileşeni ile olabilecek maksimum çıktıyı elde etme başarısına 'teknik etkinlik' denilmektedir (Bakırcı, 2006: 200). KVB'lerine ilişkin etkinlik ölçümü, oran analizi, parametrik yöntemler ve parametrik olmayan yöntemler kullanılarak yapılmaktadır (Sarı, 2015: 3-4).

Charnes vd. (1978), çok sayıda girdi ve çok sayıda çıktı olması durumunda karar verme birimlerinin göreli etkinliklerini ölçen Veri Zarflama Analizi (VZA)'ni önermişlerdir. VZA, Doğrusal Programlama tabanlı, herhangi bir varsayıma ihtiyaç duyulmayan parametrik olmayan bir yöntemdir. VZA'da etkinlik ölçütü, çıktıların ağırlıklı toplamlarının girdilerin ağırlıklı toplamlarına bölümü ile elde edilmektedir (Çağlar, 2003: 17-18).

$m$ girdi ile $s$ çıktı üreten $n$ tane KVB'nin olması durumunda, incelenen KVB'nin etkinliğini veren CCR Modeli Eşitlik (1)'deki gibidir:

Maks $\theta=\frac{\sum_{r=1}^{S} u_{r} y_{r o}}{\sum_{i=1}^{m} v_{i} x_{i o}}$ 
$\frac{\sum_{r=1}^{s} u_{r} y_{r j}}{\sum_{i=1}^{m} v_{i} x_{i j}} \leq 1 \quad(j=1,2, \ldots . n)$

$u_{r} \geq 0, v_{i} \geq 0 \quad(r=1,2, \ldots, s ; i=1,2, \ldots, m)$

Burada, $\theta$, etkinlik skoru; $x_{i j}$, j. KVB'nin i. girdisi; $y_{r j}$, j. KVB'nin r. çıktısı; $u_{r}$, r. çıktının ağırlığı; $v_{i}$, i. girdinin ağırlığıdır. Eşitlik (1)'deki modelin amaç fonksiyonu doğrusal değildir. Model, bir Kesirli Programlama modelidir. Eşitlik (1)'deki amaç fonksiyonunun paydası 1'e eşitlenerek bir kısıt olarak probleme eklenmesiyle Eşitlik (2)'deki çarpan biçim olarak da bilinen Doğrusal Programlama modeli elde edilmektedir.

Maks $\theta=\sum_{r=1}^{s} u_{r} y_{r o}$

$\sum_{i=1}^{m} v_{i} x_{i o}=1$

$\sum_{r=1}^{s} u_{r} y_{r j}-\sum_{i=1}^{m} v_{i} x_{i j} \leq 0 \quad(j=1,2, \ldots, n)$

$u_{r} \geq 0, v_{i} \geq 0 \quad(r=1,2, \ldots, s ; i=1,2, \ldots, m)$

Eşitlik 2'nin dualinin alınması ile zarflama biçimi olarak bilinen model elde edilmektedir:

$\operatorname{Min} \theta$

$\theta x_{i o}-\sum_{j=1}^{n} \lambda_{j} x_{i j} \geq 0 \quad(i=1,2, \ldots, m)$

$\sum_{j=1}^{n} \lambda_{j} y_{r j} \geq y_{r 0} \quad(r=1,2, \ldots, s)$

$\lambda_{j} \geq 0 \quad(j=1,2, \ldots, n)$

Eşitlik (1), (2) ve (3)'teki modeller, sırasıyla, kesirli, çarpan ve zarflama modelleri olarak isimlendirilir. Bu modeller girdi yönlü CCR modelleridir (Doğan ve Gencan, 2014: 96-97). Zarflama modeli çözüldüğünde $0 \leq \theta \leq 1$ olmaktadır. KVB'nin etkin olabilmesi için $\theta^{*}=1$ ve gevşek değişkenlerin tamamı sıfır olmalıdır. Verilen koşulların sağlanmaması durumunda KVB etkin olmayandır. Etkin olmayan KVB'ler etkin olabilmek için kendilerini etkin KVB'lere benzetmeye çalışırlar. Etkin olmayan KVB'lerin örnek aldıkları etkin KVB'lerin oluşturduğu küme referans kümesi olarak adlandırılır. Referans küme, zarflama modeli çözümünde $\lambda_{j}>0$ koşulunu sağlayan KVB'lerden oluşur.

Buraya kadar verilen CCR modeli, çıktılar sabit iken girdileri azaltmayı hedeflemektedir. Bu nedenle girdi yönlü CCR modeli olarak tanımlanır. Girdiler sabit tutularak çıktıları arttırmayı hedefleyen model ise çıktı yönlü CCR modelidir. Çıktı yönlü CCR modelinin zarflama biçimi Eşitlik (4)'te verilmiştir:

Maks $\eta$

$$
\begin{array}{ll}
x_{i o} \geq \sum_{j=1}^{n} \lambda_{j} x_{i j} & (i=1,2, \ldots, m) \\
\sum_{j=1}^{n} \lambda_{j} y_{r j} \geq \eta y_{r 0} & (r=1,2, \ldots, s)
\end{array}
$$


$\lambda_{j} \geq 0 \quad(j=1,2, \ldots, n)$

Eşitlik (4)'teki model çözüldüğünde $\eta \geq 1$ değerini almaktadır. KVB'nin etkin olabilmesi için $\eta^{*}=1$ ve gevşek değişkenlerin tamamı sıfır olmalıdır. Verilen koşulların sağlanmaması durumunda KVB etkin olmayandır. Yine, girdi yönlü modelde olduğu gibi referans küme, çözümde $\lambda_{j}>0$ koşulunu sağlayan KVB'lerden oluşmaktadır. VZA'da oluşturulan model incelenen KVB içindir ve her bir KVB için tek tek olmak üzere toplam $n$ adet model oluşturularak çözümlenir.

VZA, her KVB için en yüksek etkinlik skorunun elde edilmesini sağlayacak ağılıkları atamaktadır. Incelenen KVB için dezavantajlı değişkenlere sıfır ya da çok küçük ağırlıklar atanabilmektedir. Ağılıkların sıfır ya da çok küçük olması etkinlik skoru hesaplanmasında bazı değişkenlerin katkııının olmamasına ya da istenenden çok az olmasına yol açmaktadır. Bu sorunu gidermek için VZA'da değişkenlere ilişkin ağırlıklara sınırlamalar getirmek mümkündür. Ayrıca, girdi ve çıktı değişkenlerine ilişkin ağırlıklara kısıtların eklenmesiyle modelin ayırma gücü de artar (Özdemir ve Demireli, 2013: 9). Ağırlıkların birbirine oranına sınır getirilmesini sağlayan Garanti (Güven) Bölgesi (AR) Yaklaşımını Thompson vd. (1986) önermiştir. AR Yaklaşımına göre ağırlıklar Eşitlik (5) ve Eşitlik (6)'daki gibi sınırlanır.

$\alpha_{k l} \leq \frac{v_{k}}{v_{l}} \leq \beta_{k l} \quad(k \neq l)$

$\delta_{r p} \leq \frac{u_{r}}{u_{p}} \leq \gamma_{r p} \quad(r \neq p)$

Burada, $\alpha_{k l}$ ve $\beta_{k l}$ girdilere ilişkin ağırlık oranı olan $v_{k} / v_{l}$ için alt ve üst sınır değerleri; $\delta_{r p}$ ve $\gamma_{r p}$ çıktılara ilişkin ağırlık oranı $u_{r} / u_{p}$ için alt ve üst sınır değerleridir. Eşitlik (5) ve/veya Eşitlik (6)'daki kısıtlar VZA modellerine eklenerek AR yaklaşımı yardımıyla KVB'lerin etkinlik skorları belirlenebilmektedir.

\section{3. Çalışmanın Veri Seti}

illerde yaşam kalitesinin belirlenmesi için TÜik'in endeksine alternatif bir hesaplama yaklaşımı önerileceğinden TÜiK tarafından kullanılan boyutlar ve göstergeler tercih edilmiştir. Çaıışmada kullanılan göstergeler ve boyutlar üzerinde herhangi bir tartışma yapılmadan hesaplama yöntemine odaklanılmıştır. TÜiK tarafından hesaplanan illerin yaşam endeksinde Tablo 1'de verilen Konut, Çalışma Hayatı, Gelir ve Servet, Sağlık, Eğitim, Çevre, Güvenlik, Sivil KatıIım, Altyapı Hizmetlerine Erişim, Sosyal Yaşam ve Yaşam Memnuniyeti olmak üzere 11 alt boyutta toplam 41 gösterge kullanılmaktadır.

Mahlberg ve Obersteiner (2001), 182 ülkeyi baz alarak UNDP tarafından hesaplanan IGE'yi bu ülkeler için VZA yöntemi ile yeniden değerlendirmiştir. Benzer bileşik endeksli ve çok sayıda girdi ve çıktısı bulunan modellerde de VZA'nın kullanılabileceği ifade edilmiştir (Mahlberg ve Obersteiner, 2001: 2-3). Bu çalışmada illerin YKE belirlenirken önce Mahlberg ve Obersteiner (2001)'in önerdiği model ile her bir boyut için birer tane olmak üzere 11 alt endeks (AE) hesaplanmıştır. Her bir AE hesaplanırken ayrı ayrı çıktı yönlü CCR modeli kullanılmıştır. Modelde, her bir alt endeksin hesaplanmasında ilgili boyutta yer alan göstergeler çıktı olarak belirlenmiştir. Herhangi bir göstergenin minimum olması tercih ediliyor ise bu göstergenin tersi alınmıştır. Tablo 1'de katkı yönü negatif olan 9 göstergenin tersi alınarak modellerde yer verilmiştir. Modelde girdi olarak ise tüm iller için değeri 1 olan yapay bir değişken kullanılmıştır. Böylece, 81 il için alt endeksler belirlenirken, bir girdi ve alt endekse ilişkin boyutta yer alan sayıda çıktı elde edilmiştir. TÜiK'in boyutlara ilişkin hesaplamalarında göstergeler minimum-maksimum kriterine göre normalize edilmesine rağmen VZA'da orijinal biçimi ile 
modelde yer almıştır. Kullanılabilecek normalizasyon türünün sonuçları etkileyebileceği düşünüldügünde VZA'da orijinal değerlerin kullanılması bir avantaj olarak değerlendirilebilir. Ayrıca, TÜik, her bir alt endekste kullanılan değişkenlere eşit ağırlık verirken, VZA her bir il için YKE'yi en büyük yapacak ağırlık seçimini veriye dayalı olarak yapmakta, herhangi bir önsel bilgi kullanmamaktadır. Olası önsel bilginin modele eklenebilmesi de mümkündür.

Çıktı yönlü modellerde amaç fonksiyonunun değeri olan etkinlik skoru 1'den büyük olmaktadır. AE olarak kullanılacak etkinlik skorunun tersi alınarak 0-1 aralığında bir alt endeks değeri elde edilmiştir. Böylece, VZA ile elde edilen alt endeks için en büyük değer 1 olacaktır. Tüm iller için 11 alt endeks VZA ile elde edildikten sonra illerin YKE belirlenmiştir. Bu noktada, TÜiK gibi alt endekslerin aritmetik ortalaması ile YKE belirlemek yerine, UNDP'nin iGE'yi belirlerken izlediği yol gibi YKE alt endekslerin geometrik ortalaması alınarak bulunmuştur:

$Y K E_{j}=\sqrt[11]{A E_{j 1} \cdot A E_{j 2} \cdot \cdots \cdot A E_{j 11}}=\left(\prod_{i=1}^{11} A E_{j i}\right)^{\frac{1}{11}} \quad, \quad j=1,2, \ldots, 81$

Burada, $Y K E_{j}$, j. il için yaşam kalite endeksi; $A E_{j i}$, j. il için i. alt endeks değeridir. Herhangi bir il için tüm AE değerleri 1 ise YKE değeri 1 olur. illerin, hem her bir AE değerine göre ve hem de elde edilen YKE değerine göre sıralanarak yaşam kalitesine göre karşılaştırılmaları mümkün olmaktadır. Böylece, YKE'nin geliştirilmesi için hangi boyuta odaklanmak gerektiği de ortaya çıkmaktadır. Üstelik, yapısı gereği VZA, herhangi bir boyutta etkin olmayan ilin boyuttaki hangi göstergeye göre gelişim sağlaması gerektiğini belirlemeye olanak sağlamaktadır.

\section{4. Çalışmanın Bulguları}

Çalışmada illerin Yaşam Kalitesi Endeksi'ni belirlemek için iki yaklaşım kullanılmıştır. Önce CCR Modeli ile alt endeksler bulunmuş ve sonra Eşitlik (7) ile her il için YKE belirlenmiştir. İkinci olarak CCR modelinde çıktı olarak kullanılan göstergelere ağırlık sınırlandırması yapılmıştır. Girdi sayısı bir olduğundan girdi için herhangi bir sınırlandırma yapılması mümkün değildir. Göstergelere ilişkin ağılık sınırlandırması yapılarak uygulanan AR Yaklaşımı yardımıyla alt endeksler elde edilmiş ve daha sonra Eşitlik (7) ile her il için YKE belirlenmiştir.

\subsection{CCR Modeli Bulguları}

İllerin Eşitlik (4)'teki CCR Modeli ile elde edilen AE değerleri ve YKE değerleriyle birlikte illerin sıralamaları Tablo 2'de verilmiştir. Tablo 2'de her boyuta ilişkin ilk sütunda ilgili boyuta ait $A E$ değeri, ikinci sütunda ise ilgili boyutta ilin sırası gösterilmiştir. Tabloda verilen AE değeri 1 olan iller aynı skora sahip olduğu için aynı sırayı almaktadır. Alt endekslerin pek çoğunda CCR Modeli ile çok sayıda il 1 endeks skoruna sahip olmuştur.

Konut alt endeksinde Bolu, Düzce, Karabük ve Sakarya 1 skoruna sahip olurken Zonguldak beşinci sırayı almıştır. Ağrı, Iğdır, Kars, Ardahan ve Mardin illeri bu endekste en düşük endeks skoruna sahip olan illerdir. Çalışma Hayatı alt endeksinde Ardahan, Bartın, Karaman, Manisa, Rize, Uşak, Zonguldak olmak üzere yedi il 1 endeks skoru ile en üst sırada bulunurken son beş sıradaki iller Şanlıurfa, Van, Batman, Mardin ve Adıyaman olarak gerçekleşmiştir. Gelir ve Servet endeksinde Ankara, Düzce, Isparta, İstanbul 1 endeks skorunu alırken beşinci sırada Uşak bulunmaktadır. Son beş sıradaki iller ise Muş, Şanlıurfa, Ağrı, Ardahan ve Adıyaman'dır. Sağlık endeksindeki skorlar incelendiğinde 11 alt endekste illerin en yakın endeks skorlarının olduğu boyutun Sağıık boyutu olduğu görülmektedir. Illerin genel olarak yüksek skora sahip olduğu bu endekste on altı ilin endeks skoru 1 olmuştur. En düşük endeks skorunun 0.939 olduğu Sağlık boyutunda en düşük endeks değerine sahip iller Gaziantep, Ardahan, Van, Ağrı 
ve Kilis olmuştur. Eğitim alt endeksinde 11 ilin skoru tam endeks skoru olan 1 olmuştur. Son beş sırada yer alan iller ise Ağrı, Mardin, Ardahan, Şırnak ve Hakkari olmuştur. Çevre endeksi incelendiğinde illerin \% 25'i (21 il) 1 endeks skoruna sahiptir. Her ne kadar 1 endeks skoruna sahip il sayısı oldukça fazla olsa da son beş sıradaki illerin endeks skorları 0.657 ve daha düşük olmuştur. Son beş sıradaki iller ise Bitlis, Iğdır, Kars, Hakkari ve Muş olarak gerçekleşmiştir. Güvenlik boyutunda Afyonkarahisar, Artvin, Bayburt, Erzincan, Hakkari ve Şanlıurfa en yüksek endeks skoruna ve İzmir, Şırnak, Antalya, Ankara ve Düzce en düşük endeks skoruna sahip olmuştur. Sivil Katılım endeksinde Bilecik, Çorum, Kocaeli, Manisa, Rize, Sakarya ve Sivas en yüksek skora sahip iller olmuştur. En düşük endeks skoruna sahip iller ise Diyarbakır, Muş, Van, Hakkari ve Ağrı olarak gerçekleşmiştir. Ankara, Bursa, İstanbul, Karaman, Konya Altyapı Hizmetlerine Erişim boyutundaki en yüksek ve Bingöl, Ardahan, Iğdır, Muş ve Hakkari en düşük endeks skoruna sahip illerdir. Sosyal Yaşam alt boyutunda sekiz il en yüksek skora sahiptir. Bu illerin yedi tanesi Ankara ve batısında iken Ankara'nın doğusunda yer alan tek il Sinop'tur. En düşük endeks skoruna sahip beş il Şırnak, Mardin, Iğdır, Muş ve Hakkari'dir. Son alt boyut olan Yaşam Memnuniyeti'nde bir gösterge bulunduğundan göstergedeki sıralama ile endeks skoru sıralaması aynı olacaktır. Buna göre en yüksek skora sahip beş il Sinop, Afyonkarahisar, Bayburt, Kırıkkale ve Kütahya biçiminde iken en düşük skora sahip beş il Hatay, Antalya, Diyarbakır, Osmaniye ve Tunceli şeklindedir.

Alt boyutların endeks değerlerinin geometrik ortalamasından oluşturulan YKE sonuçları incelendiğinde yaşam kalitesi en iyi olan beş il Isparta, Uşak, Kütahya, Afyonkarahisar ve İstanbul'dur. Yaşam kalitesi en kötü olan beş il ise Adıyaman, Iğdır, Hakkari, Ağrı ve Muş olarak elde edilmiştir.

Tablo 2: Illerin CCR Modeliyle Elde Edilen Alt Endeks ve Yaşam Kalitesi Endeksi Değerleri

\begin{tabular}{lcccccccccccc}
\hline IIller & \multicolumn{2}{c}{ Konut } & \multicolumn{3}{c}{$\begin{array}{c}\text { Çalışma } \\
\text { Hayatı }\end{array}$} & $\begin{array}{c}\text { Gelir ve } \\
\text { Servet }\end{array}$ & Sağlık & Eğitim & \multicolumn{2}{c}{ Çevre } \\
\hline \hline Isparta & 0.949 & 29 & 0.995 & 8 & 1.000 & 1 & 1.000 & 1 & 1.000 & 1 & 0.963 & 36 \\
Uşak & 0.914 & 41 & 1.000 & 1 & 0.974 & 5 & 1.000 & 1 & 0.989 & 26 & 1.000 & 1 \\
Kütahya & 0.979 & 16 & 0.990 & 10 & 0.954 & 6 & 1.000 & 1 & 0.989 & 27 & 1.000 & 1 \\
Afyonkarahisar & 0.903 & 45 & 0.977 & 16 & 0.767 & 41 & 1.000 & 1 & 1.000 & 1 & 1.000 & 1 \\
İstanbul & 0.994 & 11 & 0.937 & 34 & 1.000 & 1 & 0.986 & 31 & 0.994 & 19 & 1.000 & 1 \\
Sakarya & 1.000 & 1 & 0.952 & 29 & 0.787 & 30 & 1.000 & 1 & 0.973 & 46 & 1.000 & 1 \\
Bilecik & 0.975 & 17 & 0.984 & 14 & 0.877 & 11 & 0.973 & 64 & 0.971 & 47 & 0.975 & 33 \\
Bolu & 1.000 & 1 & 0.968 & 21 & 0.925 & 8 & 1.000 & 1 & 0.976 & 41 & 0.958 & 38 \\
Kırıkkale & 0.950 & 27 & 0.973 & 18 & 0.760 & 43 & 1.000 & 1 & 0.976 & 42 & 1.000 & 1 \\
Balıkesir & 0.923 & 36 & 0.965 & 23 & 0.789 & 29 & 0.985 & 34 & 0.983 & 32 & 0.952 & 39 \\
Artvin & 0.964 & 22 & 0.974 & 17 & 0.853 & 16 & 1.000 & 1 & 0.974 & 44 & 1.000 & 1 \\
Ankara & 0.990 & 14 & 0.933 & 38 & 1.000 & 1 & 1.000 & 1 & 1.000 & 1 & 0.995 & 24 \\
Konya & 0.922 & 37 & 0.961 & 24 & 0.787 & 31 & 0.988 & 26 & 0.987 & 28 & 1.000 & 1 \\
Yalova & 0.993 & 13 & 0.945 & 32 & 0.910 & 9 & 0.989 & 25 & 1.000 & 1 & 1.000 & 1 \\
Amasya & 0.951 & 26 & 0.970 & 20 & 0.782 & 34 & 0.983 & 39 & 1.000 & 1 & 0.934 & 47 \\
Rize & 0.982 & 15 & 1.000 & 1 & 0.818 & 24 & 1.000 & 1 & 0.971 & 50 & 0.932 & 48 \\
Bursa & 0.962 & 23 & 0.955 & 28 & 0.818 & 25 & 0.975 & 52 & 0.979 & 37 & 1.000 & 1 \\
Karabük & 1.000 & 1 & 0.972 & 19 & 0.798 & 27 & 1.000 & 1 & 0.994 & 16 & 1.000 & 1 \\
Eskişehir & 0.956 & 24 & 0.931 & 39 & 0.842 & 18 & 0.976 & 50 & 1.000 & 1 & 1.000 & 1 \\
Kocaeli & 0.997 & 7 & 0.960 & 25 & 0.937 & 7 & 0.974 & 57 & 0.970 & 52 & 1.000 & 1 \\
Karaman & 0.862 & 62 & 1.000 & 1 & 0.766 & 42 & 0.992 & 21 & 0.994 & 15 & 0.944 & 40
\end{tabular}




\begin{tabular}{|c|c|c|c|c|c|c|c|c|c|c|c|}
\hline Sinop & 0.995 & 8 & 0.977 & 15 & 0.776 & 38 & 0.981 & 40 & 0.996 & 14 & 0.925 \\
\hline Bartın & 0.997 & 6 & 1.000 & 1 & 0.859 & 14 & 0.972 & 66 & 0.955 & 63 & 0.874 \\
\hline Manisa & 0.810 & 69 & 1.000 & 1 & 0.752 & 45 & 0.976 & 51 & 0.967 & 56 & 1.000 \\
\hline Tekirdağ & 0.938 & 33 & 0.985 & 12 & 0.904 & 10 & 0.968 & 70 & 0.963 & 60 & 1.000 \\
\hline İzmir & 0.945 & 32 & 0.926 & 42 & 0.866 & 13 & 0.988 & 27 & 0.999 & 12 & 1.000 \\
\hline Trabzon & 0.950 & 28 & 0.892 & 63 & 0.850 & 17 & 1.000 & 1 & 0.977 & 39 & 0.994 \\
\hline Kastamonu & 0.994 & 10 & 0.920 & 47 & 0.779 & 35 & 0.974 & 58 & 0.986 & 30 & 1.000 \\
\hline Denizli & 0.887 & 52 & 0.985 & 13 & 0.825 & 22 & 0.989 & 24 & 0.992 & 21 & 1.000 \\
\hline Çankırı & 0.946 & 30 & 0.895 & 62 & 0.833 & 20 & 0.980 & 41 & 0.955 & 62 & 0.942 \\
\hline Kırklareli & 0.899 & 47 & 0.941 & 33 & 0.856 & 15 & 0.975 & 54 & 0.990 & 25 & 0.965 \\
\hline Kayseri & 0.946 & 31 & 0.902 & 60 & 0.826 & 21 & 0.978 & 44 & 0.990 & 24 & 0.998 \\
\hline Kırşehir & 0.911 & 43 & 0.933 & 36 & 0.776 & 36 & 1.000 & 1 & 1.000 & 1 & 0.930 \\
\hline Samsun & 0.995 & 9 & 0.916 & 51 & 0.768 & 40 & 0.984 & 38 & 0.986 & 31 & 0.878 \\
\hline Sivas & 0.932 & 34 & 0.906 & 58 & 0.838 & 19 & 0.977 & 46 & 0.969 & 55 & 0.940 \\
\hline Bayburt & 0.970 & 19 & 0.909 & 55 & 0.813 & 26 & 0.973 & 65 & 0.977 & 40 & 0.813 \\
\hline Erzincan & 0.892 & 50 & 0.930 & 40 & 0.776 & 37 & 0.984 & 37 & 0.973 & 45 & 0.835 \\
\hline Nevşehir & 0.901 & 46 & 0.915 & 52 & 0.795 & 28 & 0.992 & 22 & 1.000 & 1 & 0.868 \\
\hline Giresun & 0.966 & 21 & 0.919 & 48 & 0.732 & 50 & 1.000 & 1 & 0.994 & 17 & 0.804 \\
\hline Çanakkale & 0.917 & 39 & 0.929 & 41 & 0.757 & 44 & 0.974 & 55 & 0.981 & 33 & 0.854 \\
\hline Edirne & 0.911 & 42 & 0.922 & 46 & 0.786 & 32 & 0.985 & 35 & 0.994 & 18 & 0.917 \\
\hline Erzurum & 0.832 & 65 & 0.913 & 53 & 0.684 & 51 & 0.976 & 49 & 0.970 & 51 & 0.897 \\
\hline Zonguldak & 0.998 & 5 & 1.000 & 1 & 0.866 & 12 & 0.970 & 68 & 0.953 & 64 & 0.983 \\
\hline Tokat & 0.953 & 25 & 0.937 & 35 & 0.734 & 49 & 0.972 & 67 & 1.000 & 1 & 0.850 \\
\hline Antalya & 0.967 & 20 & 0.965 & 22 & 0.825 & 23 & 0.988 & 28 & 0.992 & 22 & 1.000 \\
\hline Düzce & 1.000 & 1 & 0.924 & 44 & 1.000 & 1 & 0.973 & 63 & 0.941 & 68 & 0.783 \\
\hline Aydın & 0.863 & 61 & 0.951 & 30 & 0.739 & 47 & 0.985 & 33 & 0.980 & 36 & 0.987 \\
\hline Muğla & 0.897 & 48 & 0.958 & 26 & 0.785 & 33 & 1.000 & 1 & 0.981 & 34 & 1.000 \\
\hline Niğde & 0.820 & 67 & 0.912 & 54 & 0.665 & 55 & 0.987 & 30 & 0.992 & 23 & 0.940 \\
\hline K.Maraş & 0.798 & 70 & 0.881 & 64 & 0.604 & 63 & 0.993 & 20 & 0.970 & 53 & 0.967 \\
\hline Gümüşhane & 0.889 & 51 & 0.933 & 37 & 0.772 & 39 & 0.998 & 18 & 0.986 & 29 & 0.811 \\
\hline Burdur & 0.917 & 38 & 0.993 & 9 & 0.751 & 46 & 0.985 & 32 & 1.000 & 1 & 0.876 \\
\hline Malatya & 0.903 & 44 & 0.917 & 50 & 0.637 & 61 & 0.987 & 29 & 0.980 & 35 & 0.987 \\
\hline Gaziantep & 0.872 & 58 & 0.846 & 67 & 0.600 & 64 & 0.960 & 77 & 0.970 & 54 & 0.998 \\
\hline Ordu & 0.993 & 12 & 0.917 & 49 & 0.656 & 59 & 0.996 & 19 & 0.961 & 61 & 0.900 \\
\hline Aksaray & 0.813 & 68 & 0.958 & 27 & 0.736 & 48 & 0.978 & 45 & 0.978 & 38 & 0.767 \\
\hline Çorum & 0.923 & 35 & 0.907 & 57 & 0.660 & 58 & 0.976 & 48 & 0.971 & 49 & 0.876 \\
\hline Yozgat & 0.875 & 57 & 0.903 & 59 & 0.668 & 54 & 0.974 & 59 & 0.966 & 57 & 0.859 \\
\hline Mersin & 0.875 & 56 & 0.851 & 66 & 0.597 & 65 & 0.974 & 56 & 0.996 & 13 & 0.979 \\
\hline Adana & 0.864 & 60 & 0.853 & 65 & 0.644 & 60 & 0.964 & 75 & 0.964 & 59 & 0.988 \\
\hline Hatay & 0.859 & 64 & 0.831 & 70 & 0.661 & 57 & 0.968 & 71 & 0.971 & 48 & 0.978 \\
\hline Elazı̆̆ & 0.896 & 49 & 0.896 & 61 & 0.664 & 56 & 0.985 & 36 & 0.974 & 43 & 0.871 \\
\hline Siirt & 0.882 & 54 & 0.832 & 69 & 0.679 & 52 & 0.973 & 61 & 0.945 & 67 & 0.701 \\
\hline Tunceli & 0.917 & 40 & 0.924 & 45 & 0.670 & 53 & 1.000 & 1 & 1.000 & 1 & 1.000 \\
\hline Diyarbakır & 0.864 & 59 & 0.817 & 75 & 0.537 & 72 & 0.977 & 47 & 0.939 & 70 & 0.935 \\
\hline Van & 0.823 & 66 & 0.783 & 78 & 0.507 & 76 & 0.943 & 79 & 0.926 & 75 & 0.978 \\
\hline Osmaniye & 0.794 & 71 & 0.827 & 71 & 0.614 & 62 & 0.979 & 42 & 0.964 & 58 & 0.943 \\
\hline Bingöl & 0.880 & 55 & 0.908 & 56 & 0.587 & 66 & 0.967 & 73 & 0.934 & 72 & 0.790 \\
\hline Kilis & 0.700 & 73 & 0.819 & 72 & 0.563 & 68 & 0.939 & 81 & 0.993 & 20 & 0.854 \\
\hline
\end{tabular}


Eskişehir Osmangazi Üniversitesi ïBß Dergisi

\begin{tabular}{|c|c|c|c|c|c|c|c|c|c|c|c|c|}
\hline Şanlıurfa & 0.645 & 76 & 0.797 & 77 & 0.492 & 78 & 0.967 & 72 & 0.929 & 73 & 0.861 & 60 \\
\hline Batman & 0.859 & 63 & 0.773 & 79 & 0.527 & 73 & 0.978 & 43 & 0.946 & 66 & 0.784 & 71 \\
\hline Bitlis & 0.885 & 53 & 0.818 & 73 & 0.548 & 70 & 0.966 & 74 & 0.934 & 71 & 0.657 & 77 \\
\hline Şırnak & 0.692 & 74 & 0.817 & 74 & 0.516 & 75 & 0.969 & 69 & 0.880 & 80 & 0.854 & 63 \\
\hline Mardin & 0.580 & 81 & 0.758 & 80 & 0.518 & 74 & 0.998 & 17 & 0.913 & 78 & 0.959 & 37 \\
\hline Ardahan & 0.589 & 80 & 1.000 & 7 & 0.469 & 80 & 0.955 & 78 & 0.881 & 79 & 0.940 & 44 \\
\hline Kars & 0.613 & 79 & 0.988 & 11 & 0.557 & 69 & 0.973 & 62 & 0.927 & 74 & .616 & 79 \\
\hline Adıyaman & 0.771 & 72 & 0.758 & 81 & 0.440 & 81 & 0.990 & 23 & 0.950 & 65 & 0.670 & 75 \\
\hline Iğdır & 0.625 & 78 & 0.950 & 31 & 0.580 & 67 & 0.973 & 60 & 0.939 & 69 & 0.625 & 78 \\
\hline Hakkari & 0.975 & 18 & 0.832 & 68 & 0.545 & 71 & 0.975 & 53 & 0.861 & 81 & 0.609 & 80 \\
\hline Ağrı & 0.641 & 77 & 0.926 & 43 & 0.481 & 79 & 0.940 & 80 & 0.914 & 77 & 0.669 & 76 \\
\hline Muş & 0.656 & 75 & 0.815 & 76 & 0.499 & 77 & 0.963 & 76 & 0.920 & 76 & 0.533 & 81 \\
\hline iller & \multicolumn{2}{|c|}{ Güvenlik } & \multicolumn{2}{|c|}{$\begin{array}{c}\text { Sivil } \\
\text { Katılım }\end{array}$} & \multicolumn{2}{|c|}{$\begin{array}{c}\text { Altyapı } \\
\text { Hizmetlerine } \\
\text { Erişim } \\
\end{array}$} & \multicolumn{2}{|c|}{$\begin{array}{l}\text { Sosyal } \\
\text { Yaşam }\end{array}$} & \multicolumn{2}{|c|}{$\begin{array}{c}\text { Yaşam } \\
\text { Memnuniyeti }\end{array}$} & \multicolumn{2}{|c|}{$\begin{array}{c}\text { Yaşam } \\
\text { Kalitesi } \\
\text { Endeksi } \\
\end{array}$} \\
\hline Isparta & 0.990 & 12 & 0.978 & 32 & 0.955 & 16 & 1.000 & 1 & 0.906 & 13 & 0.9756 & 1 \\
\hline Uşak & 0.974 & 16 & 0.990 & 19 & 0.872 & 36 & 1.000 & 1 & 0.931 & 8 & 0.9667 & 2 \\
\hline Kütahya & 0.966 & 19 & 0.990 & 18 & 0.772 & 56 & 1.000 & 1 & 0.950 & 5 & 0.9604 & 3 \\
\hline Afyonkarahisar & 1.000 & 1 & 0.994 & 13 & 0.944 & 20 & 0.996 & 9 & 0.984 & 2 & 0.9577 & 4 \\
\hline İstanbul & 0.902 & 56 & 0.979 & 27 & 1.000 & 1 & 1.000 & 1 & 0.752 & 50 & 0.9554 & 5 \\
\hline Sakarya & 0.943 & 32 & 1.000 & 1 & 0.966 & 13 & 0.989 & 12 & 0.897 & 15 & 0.9530 & 6 \\
\hline Bilecik & 0.964 & 21 & 1.000 & 1 & 0.948 & 18 & 0.963 & 25 & 0.818 & 30 & 0.9484 & 7 \\
\hline Bolu & 0.955 & 24 & 0.976 & 36 & 0.784 & 54 & 1.000 & 1 & 0.903 & 14 & 0.9476 & 8 \\
\hline Kırıkkale & 0.952 & 26 & 0.981 & 25 & 0.874 & 34 & 0.992 & 11 & 0.972 & 4 & 0.9454 & 9 \\
\hline Balıkesir & 0.935 & 37 & 0.984 & 22 & 0.985 & 9 & 0.970 & 18 & 0.911 & 11 & 0.9421 & 10 \\
\hline Artvin & 1.000 & 1 & 0.966 & 46 & 0.858 & 40 & 0.984 & 14 & 0.808 & 32 & 0.9412 & 11 \\
\hline Ankara & 0.783 & 80 & 0.981 & 24 & 1.000 & 1 & 1.000 & 1 & 0.724 & 64 & 0.9407 & 12 \\
\hline Konya & 0.921 & 50 & 0.994 & 10 & 1.000 & 1 & 0.945 & 46 & 0.844 & 21 & 0.9384 & 13 \\
\hline Yalova & 0.852 & 71 & 0.923 & 69 & 0.940 & 21 & 0.966 & 21 & 0.821 & 28 & 0.9380 & 14 \\
\hline Amasya & 0.973 & 17 & 0.992 & 16 & 0.933 & 22 & 0.967 & 19 & 0.850 & 19 & 0.9372 & 15 \\
\hline Rize & 0.997 & 9 & 1.000 & 1 & 0.904 & 24 & 0.938 & 51 & 0.793 & 34 & 0.9367 & 16 \\
\hline Bursa & 0.892 & 62 & 0.977 & 34 & 1.000 & 1 & 0.972 & 16 & 0.787 & 35 & 0.9351 & 17 \\
\hline Karabük & 0.936 & 36 & 0.988 & 20 & 0.944 & 19 & 0.953 & 37 & 0.726 & 63 & 0.9329 & 18 \\
\hline Eskişehir & 0.831 & 74 & 0.976 & 35 & 0.950 & 17 & 1.000 & 1 & 0.807 & 33 & 0.9310 & 19 \\
\hline Kocaeli & 0.817 & 76 & 1.000 & 1 & 0.990 & 8 & 0.899 & 73 & 0.736 & 57 & 0.9307 & 20 \\
\hline Karaman & 0.952 & 25 & 0.994 & 12 & 1.000 & 1 & 0.932 & 57 & 0.811 & 31 & 0.9280 & 21 \\
\hline Sinop & 0.995 & 10 & 0.945 & 57 & 0.674 & 70 & 1.000 & 1 & 1.000 & 1 & 0.9265 & 22 \\
\hline Bartın & 0.965 & 20 & 0.959 & 51 & 0.899 & 29 & 0.939 & 50 & 0.778 & 41 & 0.9246 & 23 \\
\hline Manisa & 0.930 & 44 & 1.000 & 1 & 0.994 & 7 & 0.962 & 27 & 0.823 & 27 & 0.9243 & 24 \\
\hline Tekirdağ & 0.898 & 59 & 0.978 & 30 & 0.885 & 32 & 0.951 & 38 & 0.728 & 61 & 0.9241 & 25 \\
\hline İzmir & 0.810 & 77 & 0.975 & 38 & 0.965 & 14 & 0.942 & 48 & 0.750 & 51 & 0.9206 & 26 \\
\hline Trabzon & 0.917 & 51 & 0.946 & 56 & 0.896 & 30 & 0.995 & 10 & 0.742 & 55 & 0.9205 & 27 \\
\hline Kastamonu & 0.978 & 14 & 0.969 & 43 & 0.809 & 51 & 0.977 & 15 & 0.772 & 43 & 0.9192 & 28 \\
\hline Denizli & 0.884 & 66 & 0.999 & 8 & 0.900 & 26 & 0.948 & 41 & 0.731 & 59 & 0.9179 & 29 \\
\hline Çankırı & 0.976 & 15 & 0.974 & 39 & 0.715 & 63 & 0.958 & 32 & 0.946 & 6 & 0.9166 & 30 \\
\hline Kırklareli & 0.903 & 55 & 0.983 & 23 & 0.973 & 10 & 0.949 & 40 & 0.685 & 69 & 0.9156 & 31 \\
\hline Kayseri & 0.887 & 64 & 0.996 & 9 & 0.970 & 12 & 0.854 & 80 & 0.748 & 53 & 0.9142 & 32 \\
\hline Kırssehir & 0.967 & 18 & 0.970 & 42 & 0.758 & 57 & 0.960 & 29 & 0.865 & 18 & 0.9118 & 33 \\
\hline
\end{tabular}




\begin{tabular}{|c|c|c|c|c|c|c|c|c|c|c|c|c|}
\hline Samsun & 0.925 & 48 & 0.974 & 40 & 0.865 & 37 & 0.928 & 60 & 0.786 & 37 & 0.9063 & 34 \\
\hline Sivas & 0.927 & 47 & 1.000 & 1 & 0.839 & 45 & 0.888 & 75 & 0.766 & 45 & 0.9050 & 35 \\
\hline Bayburt & 1.000 & 1 & 0.939 & 63 & 0.678 & 68 & 0.953 & 36 & 0.977 & 3 & 0.9037 & 36 \\
\hline Erzincan & 1.000 & 1 & 0.967 & 45 & 0.829 & 49 & 0.957 & 34 & 0.831 & 25 & 0.9037 & 37 \\
\hline Nevşehir & 0.901 & 57 & 0.979 & 28 & 0.849 & 43 & 0.934 & 53 & 0.831 & 26 & 0.9036 & 38 \\
\hline Giresun & 0.960 & 23 & 0.949 & 54 & 0.851 & 41 & 0.964 & 24 & 0.843 & 22 & 0.9034 & 39 \\
\hline Çanakkale & 0.928 & 46 & 0.977 & 33 & 0.861 & 39 & 0.929 & 58 & 0.819 & 29 & 0.8998 & 40 \\
\hline Edirne & 0.936 & 35 & 0.973 & 41 & 0.862 & 38 & 0.966 & 22 & 0.696 & 66 & 0.8998 & 41 \\
\hline Erzurum & 0.931 & 40 & 0.942 & 60 & 0.995 & 6 & 0.957 & 33 & 0.846 & 20 & 0.8996 & 42 \\
\hline Zonguldak & 0.910 & 53 & 0.966 & 47 & 0.757 & 58 & 0.904 & 72 & 0.658 & 76 & 0.8993 & 43 \\
\hline Tokat & 0.933 & 38 & 0.992 & 14 & 0.831 & 47 & 0.955 & 35 & 0.764 & 47 & 0.8973 & 44 \\
\hline Antalya & 0.801 & 79 & 0.968 & 44 & 0.890 & 31 & 0.872 & 79 & 0.641 & 78 & 0.8938 & 45 \\
\hline Düzce & 0.744 & 81 & 0.986 & 21 & 0.661 & 72 & 0.967 & 20 & 0.937 & 7 & 0.8938 & 46 \\
\hline Aydın & 0.867 & 68 & 0.976 & 37 & 0.902 & 25 & 0.917 & 66 & 0.688 & 68 & 0.8903 & 47 \\
\hline Muğla & 0.841 & 73 & 0.978 & 29 & 0.830 & 48 & 0.910 & 68 & 0.675 & 72 & 0.8899 & 48 \\
\hline Niğde & 0.946 & 30 & 0.994 & 11 & 0.810 & 50 & 0.928 & 59 & 0.836 & 24 & 0.8879 & 49 \\
\hline K.Maraş & 0.944 & 31 & 0.991 & 17 & 0.850 & 42 & 0.964 & 23 & 0.878 & 16 & 0.8868 & 50 \\
\hline Gümüşhane & 0.997 & 8 & 0.896 & 76 & 0.786 & 53 & 0.934 & 55 & 0.786 & 36 & 0.8858 & 51 \\
\hline Burdur & 0.930 & 43 & 0.992 & 15 & 0.707 & 66 & 0.905 & 71 & 0.732 & 58 & 0.8833 & 52 \\
\hline Malatya & 0.931 & 42 & 0.946 & 55 & 0.874 & 35 & 0.919 & 65 & 0.694 & 67 & 0.8807 & 53 \\
\hline Gaziantep & 0.932 & 39 & 0.930 & 66 & 0.960 & 15 & 0.962 & 26 & 0.748 & 54 & 0.8805 & 54 \\
\hline Ordu & 0.951 & 28 & 0.943 & 58 & 0.709 & 64 & 0.924 & 62 & 0.749 & 52 & 0.8737 & 55 \\
\hline Aksaray & 0.952 & 27 & 0.942 & 59 & 0.708 & 65 & 0.960 & 28 & 0.874 & 17 & 0.8728 & 56 \\
\hline Çorum & 0.884 & 65 & 1.000 & 1 & 0.727 & 62 & 0.945 & 44 & 0.728 & 60 & 0.8651 & 57 \\
\hline Yozgat & 0.940 & 33 & 0.928 & 67 & 0.739 & 60 & 0.906 & 70 & 0.782 & 40 & 0.8618 & 58 \\
\hline Mersin & 0.866 & 70 & 0.961 & 50 & 0.900 & 27 & 0.899 & 74 & 0.680 & 71 & 0.8613 & 59 \\
\hline Adana & 0.823 & 75 & 0.956 & 52 & 0.915 & 23 & 0.880 & 76 & 0.682 & 70 & 0.8592 & 60 \\
\hline Hatay & 0.843 & 72 & 0.962 & 49 & 0.880 & 33 & 0.906 & 69 & 0.648 & 77 & 0.8564 & 61 \\
\hline Elazığ & 0.892 & 63 & 0.940 & 62 & 0.774 & 55 & 0.934 & 54 & 0.666 & 74 & 0.8555 & 62 \\
\hline Siirt & 0.947 & 29 & 0.962 & 48 & 0.660 & 73 & 0.989 & 13 & 0.923 & 9 & 0.8540 & 63 \\
\hline Tunceli & 0.894 & 60 & 0.903 & 74 & 0.645 & 74 & 0.923 & 63 & 0.541 & 81 & 0.8401 & 64 \\
\hline Diyarbakır & 0.878 & 67 & 0.884 & 77 & 0.970 & 11 & 0.912 & 67 & 0.627 & 79 & 0.8363 & 65 \\
\hline Van & 0.866 & 69 & 0.880 & 79 & 0.900 & 28 & 0.959 & 30 & 0.756 & 49 & 0.8357 & 66 \\
\hline Osmaniye & 0.899 & 58 & 0.978 & 31 & 0.787 & 52 & 0.932 & 56 & 0.589 & 80 & 0.8344 & 67 \\
\hline Bingöl & 0.940 & 34 & 0.931 & 65 & 0.594 & 77 & 0.948 & 42 & 0.766 & 46 & 0.8285 & 68 \\
\hline Kilis & 0.908 & 54 & 0.980 & 26 & 0.729 & 61 & 0.945 & 45 & 0.784 & 38 & 0.8268 & 69 \\
\hline Şanlıurfa & 1.000 & 1 & 0.941 & 61 & 0.837 & 46 & 0.948 & 43 & 0.738 & 56 & 0.8166 & 70 \\
\hline Batman & 0.923 & 49 & 0.918 & 72 & 0.744 & 59 & 0.944 & 47 & 0.673 & 73 & 0.8124 & 71 \\
\hline Bitlis & 0.961 & 22 & 0.934 & 64 & 0.630 & 75 & 0.958 & 31 & 0.761 & 48 & 0.8088 & 72 \\
\hline Şırnak & 0.807 & 78 & 0.925 & 68 & 0.672 & 71 & 0.878 & 77 & 0.919 & 10 & 0.7999 & 73 \\
\hline Mardin & 0.928 & 45 & 0.902 & 75 & 0.840 & 44 & 0.874 & 78 & 0.664 & 75 & 0.7959 & 74 \\
\hline Ardahan & 0.893 & 61 & 0.921 & 71 & 0.589 & 78 & 0.940 & 49 & 0.782 & 39 & 0.7929 & 75 \\
\hline Kars & 0.999 & 7 & 0.905 & 73 & 0.679 & 67 & 0.922 & 64 & 0.728 & 62 & 0.7923 & 76 \\
\hline Adıyaman & 0.931 & 41 & 0.952 & 53 & 0.677 & 69 & 0.851 & 81 & 0.837 & 23 & 0.7845 & 77 \\
\hline Iğdır & 0.993 & 11 & 0.922 & 70 & 0.507 & 79 & 0.924 & 61 & 0.767 & 44 & 0.7796 & 78 \\
\hline Hakkari & 1.000 & 1 & 0.870 & 80 & 0.362 & 81 & 0.970 & 17 & 0.909 & 12 & 0.7774 & 79 \\
\hline Ağrı & 0.912 & 52 & 0.838 & 81 & 0.619 & 76 & 0.937 & 52 & 0.774 & 42 & 0.7698 & 80 \\
\hline Muş & 0.983 & 13 & 0.883 & 78 & 0.458 & 80 & 0.950 & 39 & 0.704 & 65 & 0.7344 & 81 \\
\hline
\end{tabular}




\subsection{AR Yaklaşımı Bulguları}

VZA illerin alt boyutlardaki endeks skorlarını en büyük yapacak şekilde modeldeki göstergelere ağırıkları atamaktadır. Bu nedenle, her bir alt boyutta tüm iller için ağılık kümesi farklı olmaktadır. Ayrıca, ilin ilgili boyuttaki alt endeks skorunu maksimum yapmak için modeldeki göstergelerde il için dezavantaj taşıyan gösterge(ler)e çok küçük ağırlıklar atanmakta ve hatta çoğunlukla 0 değeri ağırlık olarak belirlenmektedir. Böylece, endeks hesabına tüm göstergeler katkı sağlayamamaktadır. Bu durumun önüne geçerek, 0 ya da çok küçük ağırlıklar atanması yerine daha dengeli bir ağırık kümesi atanması için AR yaklaşımı ile alt endeksler yeniden hesaplanmıştır. Bu amaçla, AR yaklaşımında çıktı değişkenlerine (göstergelerine) ilişkin ağırlıkların birbirine oranlarının en az 0.10, en fazla 10 olmasını sağlayacak Eşitlik (8)'deki gibi bir kısıt kümesi modele eklenmiştir:

$0.10 \leq \frac{\mathrm{u}_{\mathrm{r}}}{\mathrm{u}_{\mathrm{p}}} \leq 10 \quad(\mathrm{r} \neq \mathrm{p})$

AR yaklaşımıyla elde edilen alt endeks skorları ve YKE sonuçları Tablo 3'te verilmiştir. Tablo 3'te her boyuta ilişkin ilk sütunda ilgili boyuta ait AE değerini, ikinci sütun ilgili boyutta ilin sırasını göstermektedir. VZA'nın yapısı gereği ağırlık sınırlandırması yapıldığında elde edilen alt endeks skorları, CCR modeliyle bulunana eşit ya da ondan daha küçük olur. Tablo 3'teki sonuçlar incelendiğinde, endeks skorları Tablo 2'deki sonuçlara göre daha düşüktür ve daha az sayıda il 1 endeks skoruna sahiptir. Bu sonuç YKE skorlarına da yansımaktadır. Konut alt endeksinde sadece Bolu 1 skoruna sahip olarak ilk sırayı alırken, sonraki sıralarda Karabük, Zonguldak ve Sakarya yer almıştır. Bu endekste son beş sırayı alan iller her ne kadar sıralaması farklı olsa da CCR modeliyle elde edilen sonuçlardaki illerle aynı olmak üzere Ağrı, Iğdır, Mardin, Kars ve Ardahan'dır. Çalışma Hayatı alt endeksinde Ardahan, Bartın, Rize, Uşak, Zonguldak olmak üzere beş il 1 endeks skoru ile en üst sırada bulunurken son beş sıradaki iller Şanlıurfa, Van, Batman, Adıyaman ve Mardin olarak gerçekleşmiştir. Gelir ve Servet endeksinde açık ara olmak İstanbul 1 endeks skorunu alırken sonraki sıralarda Ankara, Muğla, İzmir, Antalya ve Uşak bulunmaktadır. Son beş sıradaki iller ise Ağrı, Şanlıurfa, Batman, Adıyaman ve Mardin'dir. Sağlık endeksindeki skorlar incelendiğinde Afyonkarahisar, Artvin, Isparta, Kütahya, Rize ve Sakarya'nın endeks skoru 1 olmuştur. Sağlık boyutunda en düşük endeks değerine sahip iller Ardahan, Muş, Kilis, Van ve Ağrı'dır. Eğitim alt endeksinde Amasya, Burdur, Isparta, Kırşehir, Tunceli ve Yalova olmak üzere altı ilin skoru tam endeks skoru olan 1 olmuştur. Son beş sırada yer alan iller ise Mardin, Ağrı, Ardahan, Şırnak ve Hakkari'dir. Çevre endeksi incelendiğinde altı il 1 endeks skoruna sahiptir: Antalya, Denizli, İstanbul, Karabük, Kastamonu ve Muğla. Çevre boyutundaki alt endekste son beş sıradaki iller ise Hakkâri, Ağrı, Kars, Muş ve Ardahan olarak elde edilmiştir. Güvenlik alt endeksinde ilk sıralarda Afyonkarahisar, Artvin, Rize, Sinop ve Bayburt sıralaması gerçekleşmiştir. Alt sıralardaki sıralama ise Ankara, Batman, Düzce, İstanbul ve Şırnak biçimindedir. Sivil Katılım endeksinde Rize, Sakarya ve Sivas 1 skorlarıyla ilk sıradadır. Bu illeri Çorum ve Kocaeli izlemektedir. Sivil Katılım endeksinde en düşük endeks skoruna sahip iller ise Diyarbakır, Muş, Van, Hakkâri ve Ağrı sıralaması ile ağılık sınırlaması yapılmayan model ile aynı şekilde gerçekleşmiştir. Altyapı Hizmetlerine Erişim boyutunda sadece İstanbul 1 endeks skoruna sahiptir. Bu ili Adana, İzmir, Ankara ve Diyarbakır izlemektedir. Bu endekste Siirt, Iğdır, Muş, Ardahan ve Hakkâri en düşük endeks skoruna sahip son beş ildir. Sosyal Yaşam alt boyutunda Ankara, Bolu, İstanbul, Kütahya ve Uşak 1 endeks skoru ile ilk sıradadır. Sosyal Yaşam endeksinde en düşük endeks skoruna sahip beş il ise Tunceli, Muş, Iğdır, Mardin ve Şırnak'tır. Son alt boyut olan Yaşam Memnuniyeti'nde bir gösterge bulunduğundan ağırlık sınırlandırması yapılmayan modeldeki gibi göstergedeki sıralama ile endeks 
skoru sıralaması aynı olacaktır. Buna göre en yüksek skora sahip beş il Sinop, Afyonkarahisar, Bayburt, Kırıkkale ve Kütahya biçiminde iken en düşük skora sahip beş il ise Hatay, Antalya, Diyarbakır, Osmaniye ve Tunceli şeklindedir.

Ağırık sınırlandırması altında bulunan alt boyutların endeks değerlerinin geometrik ortalamasından oluşturulan YKE sonuçları incelendiğinde yaşam kalitesi en iyi olan beş il i̇stanbul, Ankara, İzmir, Uşak ve Isparta'dır. Yaşam kalitesi en kötü olan beş il ise Ardahan, Şırnak, Ağrı, Hakkâri ve Muş olarak gerçekleşmiştir.

Tablo 3: IIllerin AR Yaklaşımıyla Elde Edilen Alt Endeks ve Yaşam Kalitesi Endeksi Değerleri

\begin{tabular}{|c|c|c|c|c|c|c|c|c|c|c|c|c|}
\hline \multirow{2}{*}{$\begin{array}{l}\text { İller } \\
\text { İstanbul }\end{array}$} & \multicolumn{2}{|c|}{ Konut } & \multicolumn{2}{|c|}{$\begin{array}{l}\text { Çalışma } \\
\text { Hayatı }\end{array}$} & \multicolumn{2}{|c|}{$\begin{array}{c}\text { Gelir ve } \\
\text { Servet }\end{array}$} & \multicolumn{2}{|c|}{ Sağlık } & \multicolumn{2}{|c|}{ Eğitim } & \multicolumn{2}{|c|}{ Çevre } \\
\hline & 0.974 & 12 & 0.936 & 35 & 1.000 & 1 & 0.965 & 53 & 0.969 & 43 & 1.000 & 1 \\
\hline Ankara & 0.971 & 14 & 0.931 & 38 & 0.645 & 2 & 0.973 & 36 & 0.990 & 13 & 0.964 & 20 \\
\hline İzmir & 0.928 & 31 & 0.926 & 41 & 0.580 & 4 & 0.971 & 39 & 0.980 & 28 & 0.973 & 16 \\
\hline Uşak & 0.897 & 37 & 1.000 & 1 & 0.427 & 6 & 0.993 & 8 & 0.981 & 23 & 0.905 & 36 \\
\hline Isparta & 0.931 & 28 & 0.995 & 6 & 0.348 & 18 & 1.000 & 1 & 1.000 & 1 & 0.951 & 25 \\
\hline Yalova & 0.975 & 11 & 0.945 & 31 & 0.420 & 7 & 0.986 & 18 & 1.000 & 1 & 0.921 & 31 \\
\hline Balıkesir & 0.873 & 45 & 0.953 & 25 & 0.368 & 14 & 0.974 & 35 & 0.981 & 26 & 0.924 & 30 \\
\hline Bursa & 0.944 & 22 & 0.953 & 26 & 0.361 & 15 & 0.970 & 41 & 0.976 & 36 & 0.996 & 7 \\
\hline Muğla & 0.880 & 42 & 0.958 & 24 & 0.584 & 3 & 0.988 & 14 & 0.978 & 30 & 1.000 & 1 \\
\hline Eskişehir & 0.937 & 23 & 0.928 & 40 & 0.374 & 13 & 0.964 & 59 & 0.993 & 9 & 0.986 & 11 \\
\hline Antalya & 0.949 & 20 & 0.965 & 22 & 0.471 & 5 & 0.968 & 47 & 0.990 & 14 & 1.000 & 1 \\
\hline Denizli & 0.870 & 47 & 0.984 & 11 & 0.403 & 9 & 0.984 & 20 & 0.992 & 11 & 1.000 & 1 \\
\hline Trabzon & 0.933 & 26 & 0.892 & 61 & 0.331 & 21 & 0.992 & 11 & 0.977 & 34 & 0.986 & 13 \\
\hline Sakarya & 0.979 & 5 & 0.952 & 27 & 0.224 & 42 & 1.000 & 1 & 0.966 & 46 & 0.988 & 10 \\
\hline Afyonkarahisar & 0.887 & 40 & 0.969 & 16 & 0.233 & 40 & 1.000 & 1 & 0.982 & 21 & 0.891 & 38 \\
\hline Kocaeli & 0.977 & 7 & 0.958 & 23 & 0.322 & 22 & 0.961 & 64 & 0.969 & 44 & 0.990 & 8 \\
\hline Bolu & 0.982 & 2 & 0.968 & 18 & 0.265 & 35 & 0.992 & 12 & 0.976 & 35 & 0.910 & 34 \\
\hline Konya & 0.905 & 35 & 0.938 & 33 & 0.237 & 39 & 0.985 & 19 & 0.975 & 37 & 0.989 & 9 \\
\hline Kayseri & 0.928 & 30 & 0.902 & 58 & 0.290 & 29 & 0.968 & 48 & 0.981 & 22 & 0.960 & 22 \\
\hline Tekirdağ & 0.921 & 33 & 0.985 & 10 & 0.315 & 24 & 0.962 & 63 & 0.956 & 58 & 0.969 & 17 \\
\hline Karabük & 0.982 & 3 & 0.972 & 15 & 0.250 & 37 & 0.976 & 30 & 0.993 & 8 & 1.000 & 1 \\
\hline Aydın & 0.775 & 71 & 0.951 & 29 & 0.379 & 11 & 0.978 & 25 & 0.977 & 33 & 0.978 & 14 \\
\hline Kırklareli & 0.845 & 59 & 0.941 & 32 & 0.377 & 12 & 0.960 & 65 & 0.985 & 19 & 0.932 & 29 \\
\hline Karaman & 0.845 & 58 & 0.973 & 13 & 0.279 & 30 & 0.991 & 13 & 0.987 & 15 & 0.918 & 32 \\
\hline Zonguldak & 0.980 & 4 & 1.000 & 1 & 0.403 & 10 & 0.960 & 67 & 0.949 & 62 & 0.954 & 24 \\
\hline Kırşehir & 0.887 & 38 & 0.931 & 37 & 0.334 & 20 & 0.983 & 21 & 1.000 & 1 & 0.834 & 50 \\
\hline Bartın & 0.979 & 6 & 1.000 & 1 & 0.338 & 19 & 0.970 & 40 & 0.950 & 61 & 0.859 & 48 \\
\hline Kütahya & 0.961 & 16 & 0.987 & 9 & 0.200 & 50 & 1.000 & 1 & 0.986 & 17 & 0.823 & 53 \\
\hline Manisa & 0.776 & 70 & 0.966 & 21 & 0.217 & 46 & 0.974 & 34 & 0.960 & 54 & 0.986 & 12 \\
\hline Nevşehir & 0.883 & 41 & 0.912 & 51 & 0.351 & 17 & 0.976 & 28 & 0.993 & 7 & 0.804 & 55 \\
\hline Adana & 0.848 & 56 & 0.853 & 65 & 0.309 & 25 & 0.953 & 74 & 0.949 & 63 & 0.963 & 21 \\
\hline Edirne & 0.810 & 64 & 0.922 & 44 & 0.354 & 16 & 0.972 & 37 & 0.986 & 16 & 0.887 & 39 \\
\hline Çanakkale & 0.855 & 54 & 0.919 & 46 & 0.297 & 26 & 0.965 & 52 & 0.981 & 24 & 0.844 & 49 \\
\hline Sinop & 0.976 & 10 & 0.967 & 19 & 0.255 & 36 & 0.977 & 27 & 0.981 & 25 & 0.864 & 45 \\
\hline Rize & 0.963 & 15 & 1.000 & 1 & 0.229 & 41 & 1.000 & 1 & 0.965 & 49 & 0.883 & 40 \\
\hline Bilecik & 0.957 & 17 & 0.978 & 12 & 0.192 & 52 & 0.971 & 38 & 0.971 & 38 & 0.969 & 18 \\
\hline Kırıkkale & 0.932 & 27 & 0.967 & 20 & 0.175 & 56 & 0.993 & 9 & 0.970 & 41 & 0.831 & 52 \\
\hline
\end{tabular}


Eskişehir Osmangazi Üniversitesi iiBF Dergisi

\begin{tabular}{|c|c|c|c|c|c|c|c|c|c|c|c|}
\hline amsun & 0.976 & 8 & 0.916 & 49 & 0.239 & 38 & 0.976 & 31 & 0.981 & 27 & 0.860 \\
\hline Giresun & 0.947 & 21 & 0.919 & 47 & 0.267 & 32 & 0.998 & 7 & 0.993 & 10 & 0.797 \\
\hline Erzincan & 0.876 & 44 & 0.929 & 39 & 0.266 & 34 & 0.975 & 33 & 0.971 & 39 & 0.785 \\
\hline Mersin & 0.859 & 51 & 0.851 & 66 & 0.295 & 28 & 0.963 & 61 & 0.986 & 18 & 0.973 \\
\hline Artvin & 0.928 & 29 & 0.972 & 14 & 0.220 & 44 & 1.000 & 1 & 0.963 & 50 & 0.874 \\
\hline Sivas & 0.915 & 34 & 0.906 & 56 & 0.270 & 31 & 0.965 & 54 & 0.963 & 51 & 0.865 \\
\hline Burdur & 0.852 & 55 & 0.993 & 7 & 0.295 & 27 & 0.980 & 23 & 1.000 & 1 & 0.874 \\
\hline Amasya & 0.934 & 25 & 0.969 & 17 & 0.186 & 55 & 0.981 & 22 & 1.000 & 1 & 0.875 \\
\hline Kastamonu & 0.976 & 9 & 0.910 & 52 & 0.211 & 47 & 0.970 & 42 & 0.979 & 29 & 1.000 \\
\hline Aksaray & 0.797 & 67 & 0.951 & 28 & 0.318 & 23 & 0.975 & 32 & 0.966 & 47 & 0.728 \\
\hline Malatya & 0.887 & 39 & 0.917 & 48 & 0.199 & 51 & 0.976 & 29 & 0.978 & 31 & 0.945 \\
\hline Hatay & 0.842 & 61 & 0.830 & 69 & 0.267 & 33 & 0.958 & 69 & 0.962 & 52 & 0.954 \\
\hline Çankırı & 0.923 & 32 & 0.887 & 63 & 0.192 & 53 & 0.977 & 26 & 0.952 & 59 & 0.705 \\
\hline Gaziantep & 0.855 & 53 & 0.843 & 67 & 0.147 & 59 & 0.957 & 70 & 0.945 & 64 & 0.964 \\
\hline Kahramanmaraş & 0.784 & 68 & 0.880 & 64 & 0.139 & 60 & 0.988 & 15 & 0.956 & 56 & 0.943 \\
\hline Ordu & 0.974 & 13 & 0.906 & 55 & 0.201 & 49 & 0.987 & 16 & 0.956 & 57 & 0.861 \\
\hline Çorum & 0.905 & 36 & 0.887 & 62 & 0.221 & 43 & 0.963 & 60 & 0.967 & 45 & 0.795 \\
\hline Yozgat & 0.839 & 62 & 0.903 & 57 & 0.217 & 45 & 0.968 & 49 & 0.957 & 55 & 0.833 \\
\hline Tunceli & 0.857 & 52 & 0.924 & 43 & 0.404 & 8 & 0.967 & 50 & 1.000 & 1 & 0.760 \\
\hline Tokat & 0.936 & 24 & 0.937 & 34 & 0.137 & 61 & 0.969 & 45 & 0.992 & 12 & 0.782 \\
\hline Elazığ & 0.880 & 43 & 0.896 & 60 & 0.203 & 48 & 0.968 & 46 & 0.969 & 42 & 0.778 \\
\hline Niğde & 0.804 & 66 & 0.910 & 53 & 0.172 & 57 & 0.987 & 17 & 0.977 & 32 & 0.733 \\
\hline Gümüşhane & 0.872 & 46 & 0.933 & 36 & 0.161 & 58 & 0.992 & 10 & 0.983 & 20 & 0.750 \\
\hline Düzce & 1.000 & 1 & 0.924 & 42 & 0.187 & 54 & 0.963 & 62 & 0.935 & 66 & 0.687 \\
\hline Erzurum & 0.816 & 63 & 0.912 & 50 & 0.113 & 67 & 0.965 & 55 & 0.952 & 60 & 0.769 \\
\hline Bayburt & 0.951 & 19 & 0.896 & 59 & 0.133 & 63 & 0.964 & 56 & 0.970 & 40 & 0.598 \\
\hline Osmaniye & 0.779 & 69 & 0.825 & 70 & 0.119 & 66 & 0.969 & 44 & 0.960 & 53 & 0.941 \\
\hline Diyarbakır & 0.847 & 57 & 0.808 & 76 & 0.096 & 70 & 0.956 & 73 & 0.917 & 71 & 0.901 \\
\hline Van & 0.807 & 65 & 0.783 & 78 & 0.072 & 74 & 0.926 & 80 & 0.900 & 74 & 0.917 \\
\hline Siirt & 0.865 & 49 & 0.822 & 71 & 0.082 & 73 & 0.967 & 51 & 0.922 & 69 & 0.685 \\
\hline Bingöl & 0.863 & 50 & 0.908 & 54 & 0.097 & 69 & 0.952 & 75 & 0.927 & 67 & 0.608 \\
\hline Batman & 0.842 & 60 & 0.764 & 79 & 0.101 & 68 & 0.964 & 57 & 0.923 & 68 & 0.752 \\
\hline Kilis & 0.686 & 73 & 0.819 & 72 & 0.084 & 72 & 0.936 & 79 & 0.966 & 48 & 0.693 \\
\hline Adıyaman & 0.756 & 72 & 0.758 & 80 & 0.091 & 71 & 0.978 & 24 & 0.941 & 65 & 0.642 \\
\hline Iğdır & 0.598 & 78 & 0.949 & 30 & 0.135 & 62 & 0.960 & 66 & 0.916 & 72 & 0.585 \\
\hline Kars & 0.554 & 80 & 0.988 & 8 & 0.123 & 65 & 0.959 & 68 & 0.906 & 73 & 0.532 \\
\hline Şanlıurfa & 0.632 & 76 & 0.791 & 77 & 0.056 & 78 & 0.964 & 58 & 0.892 & 76 & 0.811 \\
\hline Bitlis & 0.867 & 48 & 0.818 & 73 & 0.059 & 76 & 0.957 & 71 & 0.917 & 70 & 0.590 \\
\hline Mardin & 0.569 & 79 & 0.752 & 81 & 0.068 & 75 & 0.969 & 43 & 0.889 & 77 & 0.906 \\
\hline Ardahan & 0.497 & 81 & 1.000 & 1 & 0.124 & 64 & 0.940 & 77 & 0.874 & 79 & 0.450 \\
\hline Şırnak & 0.678 & 74 & 0.809 & 75 & 0.046 & 81 & 0.945 & 76 & 0.854 & 80 & 0.708 \\
\hline Ağrı & 0.629 & 77 & 0.922 & 45 & 0.057 & 77 & 0.923 & 81 & 0.886 & 78 & 0.533 \\
\hline Hakkari & 0.955 & 18 & 0.831 & 68 & 0.050 & 80 & 0.956 & 72 & 0.836 & 81 & 0.581 \\
\hline Muş & 0.643 & 75 & 0.815 & 74 & 0.053 & 79 & 0.939 & 78 & 0.897 & 75 & 0.471 \\
\hline
\end{tabular}




\begin{tabular}{|c|c|c|c|c|c|c|c|c|c|c|c|c|}
\hline \multirow{2}{*}{$\begin{array}{l}\text { İller } \\
\text { İstanbul }\end{array}$} & \multicolumn{2}{|c|}{ Güvenlik } & \multicolumn{2}{|c|}{$\begin{array}{c}\text { Sivil } \\
\text { Katılım }\end{array}$} & \multicolumn{2}{|c|}{$\begin{array}{c}\text { Altyapı } \\
\text { Hizmetlerine } \\
\text { Erişim }\end{array}$} & \multicolumn{2}{|c|}{$\begin{array}{l}\text { Sosyal } \\
\text { Yaşam }\end{array}$} & \multicolumn{2}{|c|}{$\begin{array}{c}\text { Yaşam } \\
\text { Memnuniyeti }\end{array}$} & \multicolumn{2}{|c|}{$\begin{array}{c}\text { Yaşam } \\
\text { Kalitesi } \\
\text { Endeksi }\end{array}$} \\
\hline & 0.715 & 80 & 0.970 & 34 & 1.000 & 1 & 1.000 & 1 & 0.752 & 50 & 0.9290 & 1 \\
\hline Ankara & 0.745 & 77 & 0.976 & 24 & 0.716 & 4 & 1.000 & 1 & 0.724 & 64 & 0.8654 & 2 \\
\hline İzmir & 0.801 & 70 & 0.970 & 35 & 0.753 & 3 & 0.898 & 23 & 0.750 & 51 & 0.8564 & 3 \\
\hline Uşak & 0.974 & 6 & 0.979 & 20 & 0.506 & 46 & 1.000 & 1 & 0.931 & 8 & 0.8426 & 4 \\
\hline Isparta & 0.972 & 7 & 0.969 & 37 & 0.557 & 28 & 0.982 & 6 & 0.906 & 13 & 0.8380 & 5 \\
\hline Yalova & 0.835 & 65 & 0.915 & 69 & 0.669 & 9 & 0.920 & 17 & 0.821 & 28 & 0.8337 & 6 \\
\hline Balıkesir & 0.935 & 25 & 0.978 & 21 & 0.611 & 16 & 0.954 & 10 & 0.911 & 11 & 0.8315 & 7 \\
\hline Bursa & 0.864 & 59 & 0.970 & 32 & 0.648 & 13 & 0.952 & 12 & 0.787 & 35 & 0.8276 & 8 \\
\hline Muğla & 0.836 & 64 & 0.973 & 26 & 0.538 & 33 & 0.884 & 26 & 0.675 & 72 & 0.8273 & 9 \\
\hline Eskişehir & 0.809 & 68 & 0.971 & 30 & 0.618 & 15 & 0.954 & 11 & 0.807 & 33 & 0.8213 & 10 \\
\hline Antalya & 0.788 & 73 & 0.962 & 43 & 0.658 & 10 & 0.846 & 42 & 0.641 & 78 & 0.8195 & 11 \\
\hline Denizli & 0.875 & 54 & 0.991 & 8 & 0.560 & 27 & 0.911 & 20 & 0.731 & 59 & 0.8174 & 12 \\
\hline Trabzon & 0.874 & 55 & 0.937 & 57 & 0.695 & 7 & 0.950 & 14 & 0.742 & 55 & 0.8150 & 13 \\
\hline Sakarya & 0.942 & 22 & 1.000 & 1 & 0.576 & 21 & 0.978 & 7 & 0.897 & 15 & 0.8072 & 14 \\
\hline Afyonkarahisar & 1.000 & 1 & 0.986 & 11 & 0.544 & 31 & 0.968 & 9 & 0.984 & 2 & 0.8032 & 15 \\
\hline Kocaeli & 0.770 & 76 & 0.995 & 5 & 0.658 & 11 & 0.866 & 34 & 0.736 & 57 & 0.8029 & 16 \\
\hline Bolu & 0.945 & 19 & 0.969 & 36 & 0.485 & 51 & 1.000 & 1 & 0.903 & 14 & 0.8025 & 17 \\
\hline Konya & 0.908 & 37 & 0.985 & 13 & 0.657 & 12 & 0.935 & 15 & 0.844 & 21 & 0.8025 & 18 \\
\hline Kayseri & 0.877 & 53 & 0.988 & 9 & 0.696 & 6 & 0.820 & 54 & 0.748 & 53 & 0.7966 & 19 \\
\hline Tekirdağ & 0.870 & 57 & 0.973 & 27 & 0.566 & 24 & 0.906 & 22 & 0.728 & 61 & 0.7951 & 20 \\
\hline Karabük & 0.913 & 35 & 0.983 & 16 & 0.554 & 29 & 0.952 & 13 & 0.726 & 63 & 0.7943 & 21 \\
\hline Aydın & 0.859 & 60 & 0.970 & 33 & 0.598 & 18 & 0.870 & 33 & 0.688 & 68 & 0.7929 & 22 \\
\hline Kırklareli & 0.896 & 45 & 0.978 & 22 & 0.571 & 23 & 0.846 & 40 & 0.685 & 69 & 0.7919 & 23 \\
\hline Karaman & 0.946 & 18 & 0.983 & 15 & 0.563 & 26 & 0.852 & 37 & 0.811 & 31 & 0.7898 & 24 \\
\hline Zonguldak & 0.870 & 58 & 0.958 & 46 & 0.458 & 60 & 0.826 & 50 & 0.658 & 76 & 0.7863 & 25 \\
\hline Kırşehir & 0.964 & 10 & 0.960 & 45 & 0.458 & 58 & 0.851 & 38 & 0.865 & 18 & 0.7859 & 26 \\
\hline Bartın & 0.960 & 13 & 0.952 & 50 & 0.435 & 64 & 0.851 & 39 & 0.778 & 41 & 0.7842 & 27 \\
\hline Kütahya & 0.966 & 9 & 0.981 & 18 & 0.495 & 48 & 1.000 & 1 & 0.950 & 5 & 0.7837 & 28 \\
\hline Manisa & 0.925 & 30 & 0.994 & 6 & 0.672 & 8 & 0.892 & 24 & 0.823 & 27 & 0.7830 & 29 \\
\hline Nevşehir & 0.896 & 44 & 0.971 & 31 & 0.516 & 42 & 0.822 & 52 & 0.831 & 26 & 0.7828 & 30 \\
\hline Adana & 0.796 & 71 & 0.948 & 52 & 0.835 & 2 & 0.804 & 58 & 0.682 & 70 & 0.7823 & 31 \\
\hline Edirne & 0.927 & 28 & 0.966 & 39 & 0.518 & 41 & 0.920 & 18 & 0.696 & 66 & 0.7819 & 32 \\
\hline Çanakkale & 0.926 & 29 & 0.972 & 28 & 0.523 & 39 & 0.915 & 19 & 0.819 & 29 & 0.7808 & 33 \\
\hline Sinop & 0.984 & 4 & 0.938 & 54 & 0.398 & 72 & 0.889 & 25 & 1.000 & 1 & 0.7800 & 34 \\
\hline Rize & 0.990 & 3 & 1.000 & 1 & 0.494 & 49 & 0.846 & 41 & 0.793 & 34 & 0.7763 & 35 \\
\hline Bilecik & 0.946 & 16 & 0.993 & 7 & 0.572 & 22 & 0.834 & 45 & 0.818 & 30 & 0.7746 & 36 \\
\hline Kırıkkale & 0.947 & 15 & 0.971 & 29 & 0.532 & 35 & 0.969 & 8 & 0.972 & 4 & 0.7721 & 37 \\
\hline Samsun & 0.911 & 36 & 0.962 & 44 & 0.545 & 30 & 0.870 & 32 & 0.786 & 37 & 0.7712 & 38 \\
\hline Giresun & 0.958 & 14 & 0.937 & 56 & 0.468 & 55 & 0.881 & 29 & 0.843 & 22 & 0.7710 & 39 \\
\hline Erzincan & 0.945 & 21 & 0.956 & 48 & 0.534 & 34 & 0.873 & 31 & 0.831 & 25 & 0.7697 & 40 \\
\hline Mersin & 0.847 & 62 & 0.956 & 47 & 0.581 & 19 & 0.839 & 44 & 0.680 & 71 & 0.7664 & 41 \\
\hline Artvin & 1.000 & 1 & 0.963 & 41 & 0.461 & 57 & 0.882 & 28 & 0.808 & 32 & 0.7655 & 42 \\
\hline Sivas & 0.921 & 33 & 1.000 & 1 & 0.521 & 40 & 0.795 & 62 & 0.766 & 45 & 0.7652 & 43 \\
\hline Burdur & 0.930 & 26 & 0.986 & 12 & 0.440 & 63 & 0.830 & 47 & 0.732 & 58 & 0.7649 & 44 \\
\hline Amasya & 0.961 & 12 & 0.980 & 19 & 0.531 & 37 & 0.845 & 43 & 0.850 & 19 & 0.7639 & 45 \\
\hline
\end{tabular}


Eskişehir Osmangazi Üniversitesi iißBF Dergisi

\begin{tabular}{|c|c|c|c|c|c|c|c|c|c|c|c|c|}
\hline Kastamonu & 0.971 & 8 & 0.962 & 42 & 0.442 & 62 & 0.827 & 48 & 0.772 & 43 & 0.7571 & 46 \\
\hline Aksaray & 0.930 & 27 & 0.935 & 58 & 0.411 & 69 & 0.877 & 30 & 0.874 & 17 & 0.7547 & 47 \\
\hline Malatya & 0.904 & 40 & 0.937 & 55 & 0.564 & 25 & 0.852 & 36 & 0.694 & 67 & 0.7483 & 48 \\
\hline Hatay & 0.831 & 66 & 0.955 & 49 & 0.527 & 38 & 0.812 & 56 & 0.648 & 77 & 0.7393 & 49 \\
\hline Çankırı & 0.964 & 11 & 0.966 & 38 & 0.458 & 59 & 0.832 & 46 & 0.946 & 6 & 0.7364 & 50 \\
\hline Gaziantep & 0.902 & 41 & 0.917 & 68 & 0.641 & 14 & 0.928 & 16 & 0.748 & 54 & 0.7354 & 51 \\
\hline Kahramanmaraş & 0.938 & 23 & 0.983 & 17 & 0.531 & 36 & 0.911 & 21 & 0.878 & 16 & 0.7343 & 52 \\
\hline Ordu & 0.925 & 31 & 0.934 & 59 & 0.457 & 61 & 0.764 & 71 & 0.749 & 52 & 0.7327 & 53 \\
\hline Çorum & 0.881 & 52 & 0.999 & 4 & 0.466 & 56 & 0.772 & 69 & 0.728 & 60 & 0.7275 & 54 \\
\hline Yozgat & 0.937 & 24 & 0.920 & 66 & 0.473 & 53 & 0.740 & 76 & 0.782 & 40 & 0.7271 & 55 \\
\hline Tunceli & 0.852 & 61 & 0.896 & 75 & 0.410 & 70 & 0.739 & 77 & 0.541 & 81 & 0.7257 & 56 \\
\hline Tokat & 0.923 & 32 & 0.987 & 10 & 0.508 & 45 & 0.862 & 35 & 0.764 & 47 & 0.7213 & 57 \\
\hline Elazığ & 0.873 & 56 & 0.934 & 60 & 0.513 & 43 & 0.821 & 53 & 0.666 & 74 & 0.7196 & 58 \\
\hline Niğde & 0.945 & 20 & 0.985 & 14 & 0.482 & 52 & 0.800 & 60 & 0.836 & 24 & 0.7192 & 59 \\
\hline Gümüşhane & 0.946 & 17 & 0.892 & 76 & 0.501 & 47 & 0.794 & 63 & 0.786 & 36 & 0.7157 & 60 \\
\hline Düzce & 0.736 & 79 & 0.977 & 23 & 0.411 & 68 & 0.825 & 51 & 0.937 & 7 & 0.7138 & 61 \\
\hline Erzurum & 0.901 & 42 & 0.933 & 62 & 0.578 & 20 & 0.883 & 27 & 0.846 & 20 & 0.7054 & 62 \\
\hline Bayburt & 0.978 & 5 & 0.934 & 61 & 0.422 & 66 & 0.767 & 70 & 0.977 & 3 & 0.6952 & 63 \\
\hline Osmaniye & 0.890 & 49 & 0.965 & 40 & 0.508 & 44 & 0.781 & 66 & 0.589 & 80 & 0.6756 & 64 \\
\hline Diyarbakır & 0.771 & 75 & 0.879 & 77 & 0.707 & 5 & 0.807 & 57 & 0.627 & 79 & 0.6719 & 65 \\
\hline Van & 0.795 & 72 & 0.875 & 79 & 0.607 & 17 & 0.784 & 65 & 0.756 & 49 & 0.6495 & 66 \\
\hline Siirt & 0.905 & 39 & 0.952 & 51 & 0.362 & 77 & 0.815 & 55 & 0.923 & 9 & 0.6470 & 67 \\
\hline Bingöl & 0.883 & 51 & 0.927 & 65 & 0.383 & 74 & 0.796 & 61 & 0.766 & 46 & 0.6432 & 68 \\
\hline Batman & 0.741 & 78 & 0.907 & 72 & 0.468 & 54 & 0.775 & 67 & 0.673 & 73 & 0.6378 & 69 \\
\hline Kilis & 0.899 & 43 & 0.974 & 25 & 0.414 & 67 & 0.787 & 64 & 0.784 & 38 & 0.6338 & 70 \\
\hline Adıyaman & 0.893 & 47 & 0.940 & 53 & 0.391 & 73 & 0.742 & 75 & 0.837 & 23 & 0.6310 & 71 \\
\hline Iğdır & 0.895 & 46 & 0.914 & 70 & 0.320 & 78 & 0.729 & 79 & 0.767 & 44 & 0.6258 & 72 \\
\hline Kars & 0.915 & 34 & 0.901 & 73 & 0.375 & 75 & 0.754 & 73 & 0.728 & 62 & 0.6208 & 73 \\
\hline Şanlıurfa & 0.905 & 38 & 0.930 & 64 & 0.538 & 32 & 0.772 & 68 & 0.738 & 56 & 0.6184 & 74 \\
\hline Bitlis & 0.891 & 48 & 0.932 & 63 & 0.398 & 71 & 0.802 & 59 & 0.761 & 48 & 0.6103 & 75 \\
\hline Mardin & 0.842 & 63 & 0.897 & 74 & 0.491 & 50 & 0.718 & 80 & 0.664 & 75 & 0.6052 & 76 \\
\hline Ardahan & 0.884 & 50 & 0.911 & 71 & 0.290 & 80 & 0.748 & 74 & 0.782 & 39 & 0.5916 & 77 \\
\hline Şırnak & 0.692 & 81 & 0.918 & 67 & 0.431 & 65 & 0.717 & 81 & 0.919 & 10 & 0.5814 & 78 \\
\hline Ağrı & 0.807 & 69 & 0.830 & 81 & 0.374 & 76 & 0.756 & 72 & 0.774 & 42 & 0.5713 & 79 \\
\hline Hakkari & 0.782 & 74 & 0.861 & 80 & 0.222 & 81 & 0.826 & 49 & 0.909 & 12 & 0.5697 & 80 \\
\hline Muş & 0.816 & 67 & 0.877 & 78 & 0.294 & 79 & 0.730 & 78 & 0.704 & 65 & 0.5420 & 81 \\
\hline
\end{tabular}

\section{Sonuç}

Ülkelerin en önemli problemlerinden bir tanesi kaynakların vatandaşlara, dolayısıyla bölgelere eşit dağılımını sağlamaktır. Ancak, coğrafi, siyasi ya da ekonomik nedenlerle bunun sağlanması her zaman mümkün olamamaktadır. Karar vericilerin, politika yapıcıların bölgelerdeki eşitsizlikleri görebilmesi, eşitsizliklerin kaynağını ve hatta miktarını belirleyebilmesi problemin çözümündeki önemli adımlardır. Bölgesel eşitsizliklerin ortaya konmasında bireylerin yaşam koşulları bir sonuç olarak belirleyici rol oynamaktadır. Bu nedenle, bölgelerdeki yaşam kalitesinin nesnel ve/veya öznel göstergeler ile ölçülebilmesi gerekmektedir. Türkiye'de Tüik illerde Yaşam Endeksi ile bireylerin ve hanehalklarının yaşamını objektif ve subjektif ölçütler kullanarak yaşam boyutları ayrımında yerel düzeyde ölçmeye, karşılaştırmaya ve zaman içinde izlemeye yönelik bir endeks çalışması yapmıştır. 11 alt boyut ve 41 gösterge ile yapılan çalışmada 
minimum-maksimum normalizasyonu ile her bir göstergeye boyut içinde eşit ağırlık verilerek alt endeksler, alt boyutlardaki endekslerin aritmetik ortalaması ile Yaşam Endeksi hesaplanmaktadır. Bu çalışmada illerdeki yaşam kalitesinin belirlenmesinde alternatif bir yaklaşım önermektedir. Her bir boyuta ilişkin endeksin VZA ile oluşturulması ve genel Yaşam Kalitesi Endeksi'nin alt endekslerin geometrik ortalaması ile bulunmasını sağlayan öneride göstergelere ilişkin ağırlıkların belirlenmesinde önsel bir bilgiye ihtiyaç duyulmadan hesaplama yapmak mümkündür. Her bir alt endeksin belirlenmesinde göreli etkinlik ölçümünde kullanılan CCR modeli tercih edilirken, alt endeksin hesaplanmasında çıktı olarak ilgili boyuttaki göstergeler alınmakta ve girdi olarak Mahlberg ve Obersteiner (2001)'in önerdiği gibi her il için 1 değerinin verildiği yapay bir gösterge oluşturulmaktadır. Ayrıca, çalışmada modelin ağırlık sınırlandırması altında da kullanılabilir olduğu gösterilmiştir. Bu anlamda, istenirse uzman görüşlerine dayalı olarak gösterge ağırlıklarının sınırlandırılabileceği söylenebilir.

Ağılık sınırlandırması yapılmadan elde edilen YKE sonuçları incelendiğinde yaşam kalitesi en iyi olan beş il Isparta, Uşak, Kütahya, Afyonkarahisar ve İstanbul'dur. Yaşam kalitesi en kötü olan beş il Adıyaman, Iğdır, Hakkari, Ağrı ve Muş olarak elde edilmiştir. Ağırlık sınırlandırması altında bulunan YKE sonuçları incelendiğinde ise yaşam kalitesi en iyi olan beş il İstanbul, Ankara, İzmir, Uşak ve Isparta'dır. Yaşam kalitesi en kötü olan beş il ise Ardahan, Şırnak, Ağrı, Hakkari ve Muş olarak gerçekleşmiştir. Bu sonuçlar TÜik Yaşam Endeksi ile benzerlikler taşısa da aynı değildir. Ağırlık sınırlandırması yapılmadan elde edilen YKE'ye göre yapılan sıralamalar ile TÜiK Yaşam Endeksi ve SEGE-2011 sıralamaları arasındaki Spearman Sıra Korelasyon Katsayısı, sırasıyla, 0.972 ve 0.702 'dir. Benzer şekilde, ağırlık sınırlandırması yapıldıktan sonra elde edilen YKE'ye göre yapılan sıralamalar ile aynı endeksler arasındaki Spearman Sıra Korelasyon Katsayısı, sırasıyla, 0.840 ve 0.908 'dir. İstatistiksel olarak anlamlı olan bu katsayılar farklı yaklaşımlarla iller için elde edilen sıralamaların ilişkili olduğunu göstermektedir.

Ağılık sınırlandırması yapılmadan elde edilen YKE ile alt endekslerin arasındaki Spearman Sıra Korelasyon Katsayısı incelendiğinde, YKE ile Güvenlik alt endeksi dışındaki tüm alt endeksler arasında istatistiksel olarak anlamlı ilişki bulunmuştur. YKE ile arasındaki korelasyon katsayısı 0.70 'in üzerinde olan alt boyut Gelir ve Servet (0.855) boyutudur. Ağırlık sınırlandırması yapılarak elde edilen YKE ile alt endekslerin arasındaki Spearman Sıra Korelasyon Katsayısı incelendiğinde ise YKE ile Güvenlik ve Yaşam Memnuniyeti alt endeksleri dışındaki tüm alt endeksler arasında istatistiksel olarak anlamlı ilişki bulunmuştur. YKE ile arasındaki korelasyon katsayısı 0.70 'in üzerinde olan boyutlar Gelir ve Servet (0.881), Sosyal Yaşam (0.808) ve Çevre (0.765) olarak bulunmuştur.

Ağırlık sınırlandırması yapılmadan elde edilen sonuçlara göre ilk beş sırada yer alan iller en az üç alt boyutta 1 endeks skoruna sahiptir. Alt endekslerde son sıralarda yer alan iller, YKE sıralamasında genel olarak son yirmi sırada bulunmaktadır. Güvenlik endeksi sıralaması incelendiğinde, YKE sıralamasında 12. olan Ankara'nın 80., 26. sıradaki İzmir'in 77. sırada bulunması dikkat çekicidir. 11 alt endeksten sekizinde ilk üç içinde yer alan Ankara Yaşam Memnuniyeti endeksinde de 64. sıradadır. Ağırlık sınırlandırması yapıldıktan sonra elde edilen sonuçlar incelendiğinde ise İstanbul, Ankara ve İzmir'in üst sıralarda yer almasının en önemli nedeninin Gelir ve Servet endeksi olduğu söylenebilir. İstanbul'un Gelir ve Servet endeksindeki skorunun diğerlerine göre çok yüksek olması genel sıralamasını da etkilemektedir. YKE'ye göre ilk üç sırada bulunan İstanbul, Ankara ve İzmir'in Güvenlik endeksinde son sıralarda yer aldığı görülmektedir. 
İki farklı yaklaşımla elde edilen YKE ile 41 gösterge arasındaki Spearman Korelasyon katsayısı hesaplanmış ve \%5 anlamlılık düzeyinde incelenmiştir. Ağırlık sınırlandırması yapılmadan elde edilen YKE ile doğuşta beklenen yaşam süresi, hekim başına müracaat sayısı, PM10 istasyon değerleri ortalaması (hava kirliliği), siyasi partilere üyelik oranı, sendika/dernek faaliyetleri ile ilgili olanların oranı, havalimanına erişim oranı ve sosyal ilişkilerinden memnuniyet oranı göstergeleri arasındaki ilişki istatistiksel olarak anlamlı bulunamamıştır. Ağırlık sınırlandırması yapıldıktan sonra elde edilen YKE ile işsizlik oranı, doğuşta beklenen yaşam süresi, kamunun eğitim hizmetlerinden memnuniyet oranı, PM10 istasyon değerleri ortalaması (hava kirliliği), sokaktan gelen gürültü problemi yaşayanların oranı, cinayet oranı (bir milyon kişide), gece yalnız yürürken kendini güvende hissedenlerin oranı, kamunun asayiş hizmetlerinden memnuniyet oranı, siyasi partilere üyelik oranı, sendika/dernek faaliyetleri ile ilgili olanların oranı, havalimanına erişim oranı ve yaşam memnuniyeti göstergeleri arasındaki ilişki istatistiksel olarak anlamlı bulunamamıştır. Ayrıca, iller YKE'ne ilişkin çeyrek değerlere göre dört gruba ayrılarak en yüksek ve en düşük YKE sahip iller için 41 gösterge açısından istatistiksel olarak farklılık olup olmadığı Mann-Whitney U Testi ile incelenmiştir. Her iki yaklaşımda da hemen hemen YKE ile aralarında istatistiksel olarak ilişki olmadığı belirlenen yukarıdaki göstergeler açısından bir farklılık olmadığı görülmüştür. Bu sonuca göre, iller arasında anlamlı bir farklılık göstermeyen söz konusu göstergelerin YKE hesaplamasından çıkartılarak daha az sayıda gösterge ile endeks belirlenebilir.

Genel olarak sonuçlar incelendiğinde Türkiye'nin batısındaki illerin yaşam kalitesinin doğusundaki illere göre daha yüksek olduğu söylenebilir. Öteden beri doğu illerinden batıdaki illere göçlerin yaşandığı açıktır. Toplumsal değişme sürecinin bir sonucu olarak Türkiye'de 1950'li yıllardan itibaren zaman içinde değişen hızlarla devam eden ve genelde kırsal yerleşim yerlerinden kentsel yerleşim yerlerine ve doğu bölgelerinden batı bölgelerine doğru, temelde ekonomik nedenli olarak nitelenebilecek bir nüfus hareketi yaşanmıştır (Bülbül ve Köse, 2010: 77). Doğudaki illerin yaşam kalitesinin artırıması, illerin cazibesinin artırılarak nihayetinde çok ciddi altyapı problemleri oluşturan göçlerin önüne geçilmesi mümkün olacaktır.

YKE bulunmasında kullanılan alt endeksler VZA ile elde edilmektedir. VZA, 1 skoru almayan illerin ilgili boyutta hangi ili/illeri referans alması gerektiğini ve ilin hangi göstergelerde ne kadar bir iyileşme ile en üst seviyeye çıkabileceğini de göstermektedir. Bu çalışmada yer almayan bu durum alt endekslerde illerin potansiyel iyileştirmelerinin sağlanabileceği göstergeler hakkında bilgi verecektir.

Özet olarak, illerin yaşam kalitesinin belirlenmesi için önerilen yöntem; farklı göstergelerin bilgilerinin birleştirilerek alt endeks(ler)in belirlenebilmesi, göstergeler için herhangi bir varsayım gerektirmemesi, illeri değerlendirirken en iyi olana göre göreceli değerlendirme yapılmasına olanak sağlaması, etkin olmayan illerin göstergelere ilişkin potansiyel iyileştirmelerini belirlemeye olanak vermesi, göstergelere ilişkin ağırlık belirlenmesinde önsel bir bilgiye ihtiyaç duyulmaması ve önsel bir bilgi var ise modele eklenmesine olanak sağlanması gibi çok sayıda avantaja sahiptir. 


\section{Kaynaklar}

Acar, Yasin (2019), "Türkiye'de Yaşam Memnuniyetinin Belirleyicileri: İller Üzerine Bir Yatay Kesit Analizi", Maliye Araştırmaları Dergisi, C.5, S.2: 145-157.

Albayrak, Ali Sait (2015), "Türkiye'de Coğrafi Bölgelere Göre illerin 2012 Yılı Sosyoekonomik Gelişmişlik Sıralaması", Ekonomik ve Sosyal Araştırmalar Dergisi, C.11, S.1: 1-22.

Alpaykut, Süleyman (2017), "Türkiye'de Illerin Yaşam Memnuniyetinin Temel Bileşkenler Analizi Ve TOPSIS Yöntemiyle Ölçümü Üzerine Bir İnceleme", SDÜ Sosyal Bilimler Enstitüsü Dergisi, C.4, S.29: 367-395.

Atan, Murat; Özgür, Ebru; Güler, Hüseyin (2004), "Çok Değişkenli İstatistiksel Analizler ve VZA İle illerin Gelişmişlik Düzeylerinin Karşılaştırılması", Gazi Üniversitesi İktisadi ve Idari Bilimler Fakültesi, C:6, S.2: 25-42.

Aydın, Bahadır; Ertürk, Nuran (2017), "Türkiye'de Yaşam Memnuniyeti Endeksi Çerçevesinde Bölgesel Karşılaştırmalar", Politik Ekonomik Kuram, C.1, S.2: 118-141.

Ayyıldız, Ertuğrul; Demirci, Emrullah (2018), "Türkiye'de Yer Alan Şehirlerin Yaşam Kalitelerinin SWARA Entegreli TOPSIS Yöntemi İle Belirlenmesi", Pamukkale Üniversitesi Sosyal Bilimler Enstitüsü Dergisi, S.30: 67-87. https://doi.org/10.5505/pausbed.2018.16870

Baday Yıldız, Ezgi; Sivri, Uğur; Berber, Metin (2012), "Türkiye'de İllerin Sosyoekonomik Gelişmişlik Sıralaması (2010)", Erciyes Üniversitesi Iktisadi ve Idari Bilimler Fakültesi Dergisi, S.39: 147-167.

Bakırcı, Fehim (2006), "Sektörel Bazda Bir Etkinlik Ölçümü: VZA ile Bir Analiz", Atatürk Üniversitesi Iktisadi ve Idari Bilimler Dergisi, C.20, S.2: 199-217.

Beritan, Saim Can (2014), Küresel Kentler Bağlamında Yaşam Kalitesi Göstergelerine Kalitatif Bir Bakış : Istanbul - New York Karşılaştırması, Yayımlanmamış Doktora Tezi, Marmara Üniversitesi, Sosyal Bilimler Enstitüsü, İstanbul.

Bernini, Cristina; Guizzardi, Andrea; Angelini, Giovanni (2013) "DEA-Like Model and Common Weights Approach for the Construction of a Subjective Community Well-Being Indicator", Social Indicators Research, Vol.114, No.2: 405-424. https://doi.org/10.1007/s11205-012-0152-3.

Beşel, Furkan (2015), "2013 Yılı Yaşam Memnuniyeti Araştırması Sonuçlarının il Bazlı Ekonomik, Sosyal ve Siyasi Analizi", Karabük Üniversitesi Sosyal Bilimler Enstitüsü Dergisi, C.5, S.2: 227-236.

Bodur, Alper; Dulgeroğlu Yuksel, Yurdanur (2017), "Social Housing Production in Terms of Constructive Demolition and Quality of Life : The Example of Istanbul", Aksaray University Journal of Science and Engineering, Vol.1, No.1: 62-78. https://doi.org/10.29002/asujse.297650.

Bulut, Hasan (2019), "Türkiye'deki İlerin Yaşam Endekslerine Göre Kümelenmesi", Süleyman Demirel Üniversitesi Fen Bilimleri Enstitüsü Dergisi, C.23, S.1: 74-82. https://doi.org/10.19113/sdufenbed.444143.

Bülbül, Serpil; Köse, Ali (2010), "Türkiye'de Bölgelerarası İç Göç Hareketlerinin Çok Boyutlu Ölçekleme Yöntemi İle İncelenmesi", Istanbul Üniversitesi Işsletme Fakültesi Dergisi, $\quad$ C.39, $\quad$ S.1: 75-94. https://dergipark.org.tr/tr/download/article-file/98174.

Çağlar, A. (2003). Veri Zarflama Analizi ile Belediyelerin Etkinliklerinin Ölçümü, Yayımlanmamış Doktora Tezi, Hacettepe Üniversitesi, Fen Bilimleri Enstitüsü, Ankara.

Çağlar, Atalay; Keten, Nur Duygu (2018), "illerin İnsani Gelişme Endeksinin Veri Zarflama Analizi ille Ölçülmesi", Ege Academic Review, C.18, S.4: 565-578. https://doi.org/10.21121/eab.2018442987

Çam, Nurcan (2014), "Şehir Yaşam Kalitesinin Ölçülmesi: Kastamonu Şehir Merkezinde Bir Uygulama", Business \& Management Studies: An International Journal, C.2, S.3: 286-307. https://doi.org/10.15295/bmij.v2i3.83

Charnes, Abraham; Cooper, William W.; Rhodes, E. (1978), "Measuring the Efficiencey on Decision Making Units", European Journal of Operational Research, Vol.2, No.6: 429-444. https://doi.org/10.1016/0377-2217(78)90138-8

Diener, Ed; Suh, Enkook. M. (1997) "Measuring Quality of Life: Economic, Social, and Subjective Indicators", Social Indicators Research, Vol.40, No.1: 189-216. https://doi.org/10.1023/A:1006859511756

Dikmen, Feyyaz Cengiz; Dursun, Gülten (2016), "Well-Being and Quality of Life: Ranking of Provinces in Turkey Using MOORA Method", Social and Economic Dynamics of Development: Case Studies (Ed. Savaş Çevik; Hamza Şimşek; Harini Mittal, IJOPEC: London: 13-25.

Doğan, Nuri Özgür; Gencan, Seda (2014), "VZA / AHP Bütünleşik Yöntemi İle Performans Ölçümü: Ankara'daki Kamu Hastaneleri Üzerine Bir Uygulama", Gazi Üniversitesi Iktisadi ve Idari Bilimler Fakültesi Dergisi, C.16, S.2: 88-112.

Dülger Türkoğlu, Handan; Bölen, Fulin; Baran, Perver Korça; Marans, Robert W. (2008), "İstanbul'da Yaşam Kalitesinin Ölçülmesi", iтÜ Dergisi/a Mimarlık, Planlama, Tasarım, C.7, S.2: 103-113. Retrieved from http://itudergi.itu.edu.tr/index.php/itudergisi_a/article/view/176/165 


\section{Eskişehir Osmangazi Üniversitesi IïB Dergisi}

Eurofound (2017), European Quality of Life Survey 2016: Quality of life, quality of public services, and quality of society, Luxembourg: Publications Office of the European Union.

Evcil Türksever, A. Nilay (2001), Türkiye'de Büyükşehir Alanlarında Yaşam Kalitesinin Değerlendirilmesine Yönelik Bir Yöntem Denemesi, Yayımlanmamış Doktora Tezi, İstanbul Teknik Üniversitesi, Fen Bilimleri Enstitüsü, İstanbul.

Farquhar, Morag (1995), "Definitions of Quality of Life: A Taxonomy", Journal of Advanced Nursing, C.22, S.3: 502508.

Filiz, Zeynep (2005), "illerin Sosyo-Ekonomik Gelişmişlik Düzeylerine Göre Gruplandırılmasında Farklı Yaklaşımlar", Eskişehir Osmangazi Üniversitesi Sosyal Bilimler Dergisi, C.6, S.1: 77-100.

Geray, Cevat (1998), "Kentsel Yaşam Kalitesi ve Belediyeler", Türk Idare Dergisi, S.421: 323-345. Retrieved from http://www.tid.gov.tr//Makaleler/Yıl70-421(1998).pdf

Gonzalez, Eduard; Carcaba, Ana; Ventura, Juan (2011), "Quality of Life Ranking of Spanish Municipalities", Revista de Economía Aplicada, Vol.XIX, No.56: 123-148.

Gonzalez, Eduardo; Carcaba, Ana; Ventura, Juan; Garcia, Jesus (2011), "Measuring Quality of Life in Spanish Municipalities", Local Government Studies, Vol.37, No.2: 171-197. https://doi.org/10.1080/03003930.2011.554826

Gül, Erhan; Çevik, Bora (2014), "2010 ve 2012 Verileriyle Türkiye'de illerin Gelişmişlik Düzeyi Araştırması", https://ekonomi.isbank.com.tr/ContentManagement/Documents/ar_03_2012.pdf, (Erişim:28.12.2018).

Gül, Erhan; Çevik, Bora (2015), "2013 Verileriyle Türkiye'de illerin Gelişmişlik Düzeyi Araştırması", https://ekonomi.isbank.com.tr/ContentManagement/Documents/ar_07_2015.pdf, (Erişim:28.12.2018).

Gülel, Ferda Esin; Çağlar, Atalay; Kangallı Uyar, Sinem Güler; Karadeniz, Oğuz; Yeşilyurt, Muhammed Ensar (2017), "Türkiye'de İllere Göre İnsani Gelişme Endeksi", Pamukkale Üniversitesi Sosyal Bilimler Enstitüsü Dergisi, 27, 208216.

Gürel Üçer, Z. Aslı (2009), Kentsel Yaşam Kalitesinin Belediye Hizmetleri Kapsamında Belirlenmesine ve Geliştirilmesine Yönelik Bir Yaklaşım: Orta Ölçekli Kent Örnekleri. Yayımlanmamış Doktora Tezi, Gazi Üniversitesi, Fen Bilimleri Enstitüsü, Ankara.

Hashimoto, Akihiro; Sugita, Takeshi; Haneda, Shoko (2009), "Evaluating Shifts in Japan's Quality-Of-Life", SocioEconomic Planning Sciences, Vol.43, No.4: 263-273. https://doi.org/10.1016/j.seps.2009.01.001

Hoe, Juanita; Orrell, Martin; Livingston, Gil (2011), "Quality of Life Measures in Old Age", Principles and Practice of Geriatric Psychiatry, (Ed. Mohammed T. Abou-Saleh; Cornelius L. E. Katona; Anand Kumar), 3rd Edition, Wiley: London: 183-192.

Hwang, Shiuh-Nan; Lee, Hsuan-Shih; Tang, Szu-Chia; Hsu, Shiuh-Sheng (2013), "Measuring Quality of Life Using DEAAR: Focusing on Undesirable Factors", INFOR: Information Systems and Operational Research, Vol.51, No.2: 8491. https://doi.org/10.3138/infor.51.2.84

Karaatli, Meltem; Ömürbek, Nuri; Budak, İbrahim; Dağ, Okan (2015), "Çok Kriterli Karar Verme Yöntemleri İle Yaşanabilir IIllerin Sıralanması", Selçuk Üniversitesi Sosyal Bilimler Enstitüsü Dergisi, S.33: 215-228.

Karagöz, Yalçın; Doğan, Adem; Koçyiğit, Selma (2016), "Gelir Düzeyinin Hayat Kalitesi ve Memnuniyetine Etkisisi:Sivas İlinde Amprik Bìr Uygulama", C.Ü. Iktisadi ve Idari Bilimler Dergisi, C.17, S.1: 169-186.

Kaya, Pınar; İpekçi Çetin, Emre; Kuruüzüm, Ayşe (2011), "Çok Kriterli Karar Verme İle Avrupa Birliği Ve Aday Ülkelerin Yaşam Kalitesinin Analizi", Ekonometri ve istatistik E-Dergisi, S.13: 80-94. http://dergipark.gov.tr/iuekois/issue/8980/112038

Kısar Koramaz, Elif (2010), Yaşam Kalitesinin Yükseltilmesinde Yeşil Alanların Etkinliğinin Ölçülmesi ve Geliştirilmesine Yönelik Model Önerisi, Yayımlanmamış Doktora Tezi. İstanbul Teknik Üniversitesi Fen Bilimleri Enstitüsü, İstanbul.

Koçak, Hüseyin (2009), "Coğrafi Bilgi Sistemlerinin Kentsel Yaşam Kalitesinin Yükseltilmesine Etkileri Üzerine Bir Değerlendirme" Dumlupınar Üniversitesi Sosyal Bilimler Dergisi, S.25: 141-147. http://dergipark.gov.tr/download/article-file/55575

Mahlberg, Bernhard; Obersteiner, Michael (2001), Remeasuring the HDI by Data Envelopement Analysis. Laxenburg, Austria: IASA Interim Report. http://pure.iiasa.ac.at/6455/

Mariano, Enzo Barberio; Sobreiro, Vinicius Amorim; Rebelatto, Daisy Aparecida do Nascimento (2015), "Human Development And Data Envelopment Analysis: A Structured Literature Review", Omega, Vol.54: 33-49. https://doi.org/10.1016/j.omega.2015.01.002

Martín, Juan Carlos; Mendoza, Cira (2013), "A DEA Approach to Measure the Quality-of-Life in the Municipalities of 
the Canary Islands", Social Indicators Research, Vol.113, No.1: 335-353. https://doi.org/10.1007/sl 1205-0120096-7

Noll, Heinz-Herbert (1996) "Social Indicators And Social Reporting: The International Experience", Symposium on Measuring the Wellbeing and Social Indicators-Final Report, (Ed. Canadian Council Social Development) Canadian Council on Social Development: Ottawa: 1-24.

OECD (2017), How's Life? 2017, Paris: OECD Publishing. https://doi.org/10.1787/how_life-2017-en

Ören Ersin, Göknur (2012), Kentsel Yaşam Göstergeleri: Büyükçekmece Örneğinde Irdelenmesi, Yayımlanmamış Yüksek Lisans Tezi, Mimar Sinan Güzel Sanatlar Üniversitesi, Fen Bilimleri Enstitüsü, İstanbul.

Özarı, Çiğdem; Eren, Özge (2018), "illerin Yaşam Endeksi Göstergelerinin Çok Boyutlu Ölçekleme ve K-ortalamalar Kümeleme Yöntemi ile Analizi", Afyon Kocatepe Üniversitesi Sosyal Bilimler Dergisi, S.20, No.2: 303-313. https://doi.org/10.32709/akusosbil.427746.

Özbek, Aşır (2019), "Türkiye'deki IIllerin EDAS ve WASPAS Yöntemleri İle Yaşanabilirlik Kriterlerine Göre Sıralanması", Kırıkkale Üniversitesi Sosyal Bilimler Dergisi, C.9, S.1: 177-200. https://dergipark.org.tr/tr/download/articlefile/656946

Özdemir, Aslı; Demireli, Erhan (2013), "Ağırlık Kısıtlı Veri Zarflama Analizi İle Mevduat Bankalarının Etkinlik Ölçümüne Yönelik Bir Uygulama", Uluslararası Yönetim iktisat ve işletme Dergisi, C.9, S.19: 215-238.

Özpınar, Esra; Koyuncu, Emre (2016), Türkiye'de Insani Gelişmişlik iller Arasında Nasıl Farklılaşıyor? 81 il Iç̧in Insani Gelişmişlik Endeksi. Ankara: TEPAV (Değerlendirme Notu). https://www.tepav.org.tr/upload/files/14679291229.81_II_icin_Insani_Gelismislik_Endeksi.pdf

Pacione, Michael (2003) "Urban Environmental Quality and Human Wellbeing - A Social Geographical Perspective", Landscape and Urban Planning, Vol.65, No.1-2: 19-30. https://doi.org/10.1016/S0169-2046(02)00234-7

Peiró-Palomino, Jesus; Picazo-Tadeo, Andres J. (2018), "OECD: One or Many? Ranking Countries with a Composite Well-Being Indicator", Social Indicators Research, Vol.139, No.3: 847-869. https://doi.org/10.1007/s11205-0171747-5

Põldaru, Reet; Roots, Jüri (2014), "A PCA-DEA Approach to Measure The Quality Of Life in Estonian Counties", SocioEconomic Planning Sciences, Vol.48, No.1: 65-73. https://doi.org/10.1016/j.seps.2013.10.001

Sakarya, Adem; ỉbişoğlu, Çiğdem (2015), "Türkiye'de İllerin Sosyo-Ekonomik Gelişmişlik Endeksinin Coğrafi Ağırlıklı Regresyon Modeli İle Analizi", Marmara Coğrafya Dergisi, S.32: 211-238.

Salihoğlu, Tayfun (2016), Kentsel Yaşam Kalitesinin Yükseltilmesinde Boş Zaman Aktivitelerinin Rolü: İstanbul Örneği, Yayımlanmamış Doktora Tezi, İstanbul Teknik Üniversitesi, Fen Bilimleri Enstitüsü, İstanbul.

Sarı, Volkan İdris; Kındap, Ahmet (2018), "Türkiye'de Kentsel Yaşam Kalitesi Göstergelerinin Analizi", Sayıştay Dergisi, S.108: 39-72.

Sarı, Zuhal (2015), Veri Zarflama Analizi ve Bir Uygulama, Yayımlanmamış Yüksek Lisans Tezi, Hacettepe Üniversitesi, Fen Bilimleri Enstitüsü, Ankara.

Sarkawi, Ahmed Azilah; Abdullah, Alias; Dali, Md. Norimah (2017), "A Critical Review on the Worldwide Economist Intelligence Unit , Mercer and Monocle Quality of Life Indicators", Journal of Business and Economics, Vol.8, No.7: 584-593. https://doi.org/10.15341/jbe(2155-7950)/07.08.2017/007

Savaş Yavuzçehre, Pınar; Torlak, Sülün Evinç (2006) "Kentsel Yaşam Kalitesi ve Belediyeler: Denizli Karşıyaka Mahallesi Örneği", Süleyman Demirel Üniversitesi Sosyal Bilimler Enstitüsü Dergisi, C.2, S.4: 184-207.

Şeker, Murat (2015), "Quality of Life Index : A Case Study of İstanbul", Ekonometri ve Istatistik E-Dergisi, S.23, 1-15.

Şeker, Murat; Saldanlı, Arif; Bektaş, Hakan (2014), TRC2 Bölgesi Yaşam Kalitesi Araştırması Diyarbakır-Şanlıurfa. Diyarbakır: Karacağ Kalkınma Ajansı Yayınları.

Şeker, Murat; Saldanlı, Arif; Bektaş, Hakan (2015), TR63 Bölgesi Yaşam Kalitesi Analizi Hatay/Kahramanmaraş/Osmaniye. Hatay: Doğu Akdeniz Kalkınma Ajansı. http://www.dogaka.gov.tr/Icerik/Dosya/www.dogaka.gov.tr_507_ZD5E38HL_TR63-Bolgesi-Yasam-KalitesiAnalizi.pdf

Şen, Hülya; Çemrek, Fatih; Özaydın, Özer (2006), "Türkiye'deki illerin Sosyo-Ekonomik Gelişmişlik Düzeylerinin Belirlenmesi", SÜ iiBF Sosyal ve Ekonomik Araştırmalar Dergisi, C.11, S.6: 155-171.

Somarriba, Noelia; Pena, Bernardo (2009), Synthetic Indicators of Quality of Life in Europe", Social Indicators Research, Vol.94, No.1: 115-133. https://doi.org/10.1007/s11205-008-9356-y

The Economist Inteligence Unit (2017), "The Global Liveability Report 2017 A free overview", 


\section{Eskişehir Osmangazi Üniversitesi IïB Dergisi}

https://pages.eiu.com/rs/753-RIQ-438/images/Liveability_Free_Summary_2017.pdf, (Erişim: 27.12.2018).

The Economist Intelligence Unit (2005), "The Economist Intelligence Unit's quality-of-life index", https://www.economist.com/media/pdf/QUALITY_OF_LIFE.pdf, (Erişim: 15.02.2018).

Thompson, Russel G.; Singleton, F. D.; Thrall, Robert M., Smith, Barton A. (1986), "Comparative Site Evaluations For Locating a High-Energy Physics Lab in Texas", Interfaces, Vol.16, No.6: 35-49. https://www.jstor.org/stable/25060889

Torlak, Sülün Evinç; Savaş Yavuzçehre, Pınar (2008), "Denizli Kent Yoksullarının Yaşam Kalitesi Üzerine Bir İnceleme", Çağdaş Yerel Yöntemler, $\quad$ C.17, http://www.todaie.edu.tr/resimler/ekler/e73d2f15db7421a_ek.pdf?dergi=Cagdas Yerel Yonetimler Dergisi

TÜiK. (2018), "illerde Yaşam Endeksi Hakkında Açıklamalar", http://www.tuik.gov.tr/HbGetir.do?id=24561\&tb_id=4, (Erişim:3.10.2018).

Tunca, Halil (2017), "Denizli Kentinin Yaşam Kalitesinin Ölçülmesi", Denizli Kent Ekonomisi, (Ed. Nihal Yayla; Özcan Uzun; Atalay Çağlar), 1.Baskı, Pamukkale Üniversitesi Yayınları: Denizli: 345-360.

Ülengin, Burç; Ülengin, Füsun; Güvenç, Ümit (2001), "A Multidimensional Approach to Urban Quality of Life : The Case of Istanbul", European Journal of Operational Research, Vol.130, C.2: 361-374.

UNDP (2018a), "Human Development Indices and Indicators: 2018 Statistical Update Technical Notes", http://hdr.undp.org/sites/default/files/hdr2018_technical_notes.pdf, (Erişim:27.12.2018).

UNDP (2018b), Human Development Indices and Indicators 2018 Statistical Update. United Nations Development Programme, New York: United Nations Development Programme. http://hdr.undp.org/sites/default/files/2018_human_development_statistical_update.pdf

Uysal, Fatma Nur; Ersöz, Taner; Ersöz, Filiz (2017), "Türkiye'deki IIllerin Yaşam Endeksinin Çok Değişkenli İstatistiksel Yöntemlerle İncelenmesi", Ekonomi Bilimleri Dergisi, C.9, S.1: 49-65. https://dergipark.org.tr/tr/download/article-file/437727.

Ünsal, Aydın; Özgür, Ebru (2004), "Bölgesel Gelişimde Faktör Analizi Yaklaşımı", Gazi Üniversitesi Iktisadi ve Idari Bilimler Fakültesi Dergisi, S.1: 1-15.

WHOQOL (1997), Measuring Quality of Life. Programme On Mental Health Division of Mental Health And Prevention of Substance Abuse World Health, World Health Organization. https://www.who.int/mental_health/media/68.pdf

Yeşilyurt, Filiz; Yeşilyurt, Muhammed Ensar; Karadeniz, Oğuz; Gülel, Ferda Esin; Kabakçı Karadaeniz, Hülya; Çağlar, Atalay (2016), "Cinsiyet ve İl Kırılımlı İnsani Gelişme Endeksi: Türkiye Örneği", Ekonomi-Tek, C.5, S:3: 21-56.

Yılancı, Veli (2010), "Bulanık Kümeleme Analizi ille Türkiye'deki illerin Sosyoekonomik Açıdan Sınıflandırılması", Süleyman Demirel Üniversitesi Iiktisadi ve Idari Bilimler Fakültesi Dergisi, C.15, S.3: 453-470.

Yüce, Hasan Uğur (2018), Türkiye'de Yaşanabilir Iller Sıralaması. İstanbul Ticaret Üniversitesi Dış Ticaret Enstitüsü Tartışma Metinleri, No:160/2018-04.

Zhu, Joe (2001), "Multidimensional Quality-of-Life Measure with an Application to Fortune's Best Cities", SocioEconomic Planning Sciences, Vol.35, No.4: 263-284. https://doi.org/10.1016/S0038-0121(01)00009-X 


\section{Extended Summary}

\section{Quality of Life of The Provinces: An Index Based on Data Envelopment Analysis with Turkish Statistical Institute Data}

Studies on the measurement of social progress, which is a concept that takes life as a whole and includes other dimensions of life as well as the economic dimension, have gained intensity. In this new individual-oriented measurement, objective criteria and subjective perceptions of individuals are used together. Turkey Statistical Institute (TURKSTAT) Life Index, while serving those purposes, is also seen as an index to reveal inequality or shortcomings in the suburbs. The TURKSTAT conducted an index study to measure, compare and monitor the life of individuals and households at the local level by using objective and subjective criteria with respect to life dimensions.

One of the important points in the calculation of the Quality of Life Index (QoLI) is to determine the weights related to the indicators in each sub-index. Another challenge is the determination of the weights of the sub-indices in the creation of a general index. While determining the sub-indices in TURKSTAT Life Index, the indicators in the relevant dimension were normalized with minimum-maximum normalization, and each calculation was made by taking an equal weight within the size of the dimension it belongs. Again, the sub-indices are considered to be of the same importance, and the arithmetic mean is taken, and the Life Index is calculated.

In this study, after sub-indices are determined by Mahlberg and Obersteiner (2001), a model similar to Data Envelopment Analysis, it is recommended to obtain the geometric mean of the sub-indices in finding the QoLI. In this context, it was aimed to calculate an index based on Data Envelopment Analysis with the indicators proposed by TURKSTAT in determining the quality of life of the provinces in the study. Thus, it is aimed to introduce an approach that evaluates the provinces relatively and eliminates the problem of determining the weights of the indicators used in the calculation. In the proposed method, it is not necessary to determine the indicator weights. It is also possible to use the indicators without normalizing.

Charnes et al. (1978) proposed Data Envelopment Analysis (DEA), which measures the relative effectiveness of decision units in the case of multiple inputs and multiple outputs. DEA is a non-parametric method based on Linear Programming without any assumption. In DEA, the efficiency criterion is obtained by dividing the weighted sums of output by the weighted sums of inputs. DEA assigns weights that will ensure the highest efficacy score for each Decision Making Unit (DMU). For DMU examined in DEA, disadvantageous variables can be assigned zero or very small weights. The fact that the weights are zero or too small, causes some variables to have no contribution or too little to be desired in calculating the efficiency score. To overcome this problem, it is possible to impose restrictions on weights for variables.

In the life index of provinces calculated by TURKSTAT, 41 indicators in 11 sub-dimensions are used, namely Housing, Work Life, Income and Wealth, Health, Education, Environment, Security, Civil Participation, Access to Infrastructure Services, Social Life and Life Satisfaction. In this study, the main focus is determining QoLI with a different approach. Therefore, 2015 data on 41 indicators in 11 sub-dimensions determined by TURKSTAT were used. In this study, 11 sub-indices were calculated for each dimension. When calculating each sub-indices, the output-oriented CCR model was used separately. In the model, the indicators in the relevant dimension are determined as output in the calculation of each sub-index. If any indicator is preferred to be minimum, the inverse of this indicator is taken. The inverse of 9 indicators with negative contribution direction is taken in the models. In the model, an artificial variable with a value of 1 was used for all provinces. After obtaining 11 sub-indices with DEA for all provinces, the QoLI of the provinces was determined. The QoLI of each province was found by calculating the geometric mean of the sub-indices. Two approaches were used to calculate the sub-indices: First, sub-indices were found with the CCR Model and then QoLI was determined. Secondly, when calculating the sub-indices, the QoLI was determined after the weight restriction (AR Approach) was applied to the indicators used in the CCR model as output.

When the results of QoLI, which are found without weight restriction, are examined, the five provinces with the best quality of life are Isparta, Uşak, Kütahya, Afyonkarahisar and Istanbul. The five provinces with the worst quality of life were obtained as Adıyaman, Iğdır, Hakkari, Ağrı and Muş. When QoLı results obtained with AR Approach are examined, the five provinces with the best quality of life are Istanbul, Ankara, İmir, Uşak and Isparta. The five provinces with the worst quality of life were Ardahan, Şırnak, Ağrı, Hakkari and Muş. The overall results were analyzed, it can be said that Turkey's western provinces are better than eastern provinces. It will be possible to increase the quality of life of the provinces in the east, and to increase the attractiveness of the provinces and to prevent migration, which ultimately creates very serious infrastructure problems. 


\section{Eskişehir Osmangazi Üniversitesi IïBF Dergisi}

The relationship between QoLI obtained without weight restriction and life expectancy at birth, number of applications per physician, average of PM10 station values (air pollution), membership rate for political parties, rate of union / association activities, rate of access to the airport, and satisfaction with social relations was not statistically significant. Likewise, the relationship between QoLI obtained with weight restriction and the unemployment rate, life expectancy at birth, satisfaction with the education services of the public, the average of PM10 station values (air pollution), the ratio of those who have noise problems from the street, murder rate (in one million people), the rate of those who feel safe, the satisfaction of public security services, the membership rate of political parties, the rate of those involved in union / association activities, the rate of access to the airport and the life satisfaction was not statistically significant. In addition, the provinces were divided into four groups according to the quarterly values regarding QoLI, and whether there were statistically significant differences in terms of 41 indicators for the provinces with the highest and lowest QoLI was examined by the Mann-Whitney U Test. In both approaches, it was observed that there was no difference in terms of the indicators above, which were determined to have no meaningful statistical relationship with QoLI. According to this result, the index can be determined with a smaller number of indicators by subtracting these indicators, which do not differ significantly between the provinces, from the QoLI calculation.

As a result, the proposed method for determining the quality of life of the provinces has several advantages. By combining the information of different indicators, the sub-index can be determined. It does not require any assumptions for the indicators. When evaluating the provinces, it provides relative evaluation according to the best. It identifies potential improvements for the indicators of inefficient provinces. Preference information is not required in determining the weight of the indicators. If there is a preference information in determining the weights related to the indicators, it allows it to be added to the model. 